SYNTHESIZED FLOOD FREQUENCY FOR SMALL URBAN STREAMS IN TENNESSEE

Clarence $\mathrm{H}$. Robbins

U.S. GEOLOGICAL SURVEY

Water Resources Investigations Report 84-4182

Prepared in cooperation with the

TENNESSEE DEPARTMENT OF TRANSPORTATION and

THE U.S. DEPARTMENT OF TRANSPORTATION,

FEDERAL HIGHWAY ADMINISTRATION

Nashville, Tennessee 
UNI'TED STATES DEPARTMENT OF THE INTERIOR

WILLIAM P. CLARK, Secretary

GEOLOGICAL SURVEY

Dallas L. Peck, Director

For additional information write to:

District Chief

U.S. Geological Survey

A-413 Federal Building

U.S. Courthouse

Nashville, Tennessee 37203
Copies of this report can be purchased from:

Open-File Services Section Western Distribution $\mathrm{Br}$ anch U.S. Geological Survey Box 25425, Federal Center Lakewood, Colorado 80225

( $\mathrm{Te}$ lephone: (303) 236-7476) 


\section{CONTENTS}

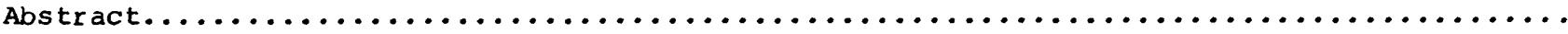

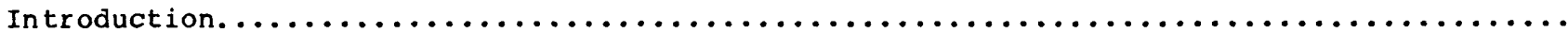

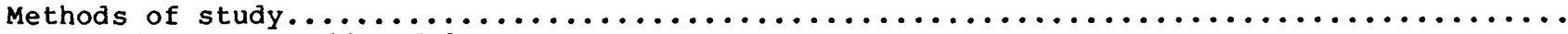

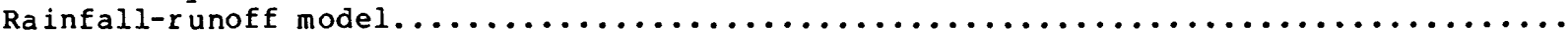

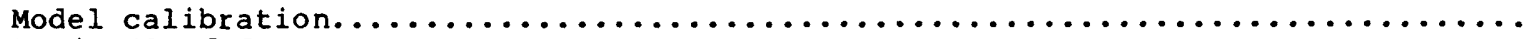

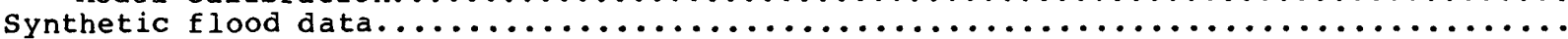

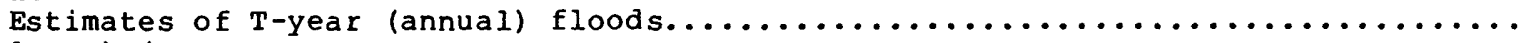

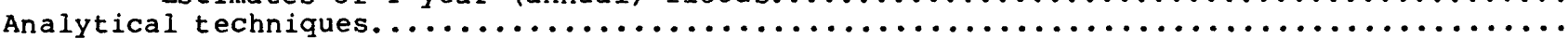

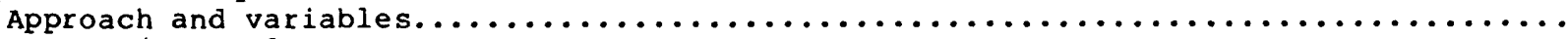

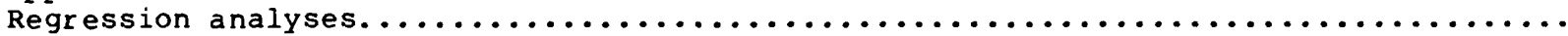

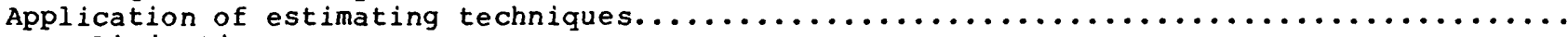

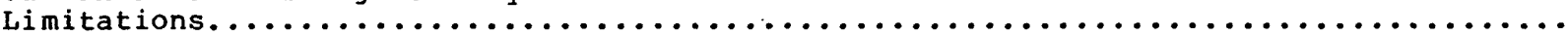

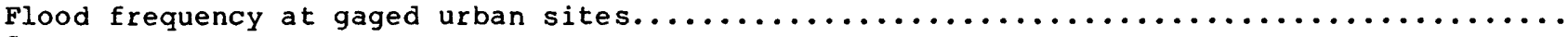

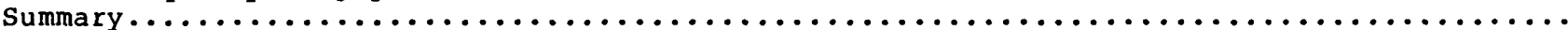

Selected references.

\section{ILLUSTRATIONS}

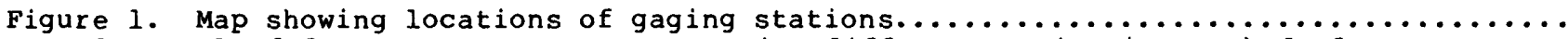

2-5. Flood-frequency curves representing different estimating methods for:

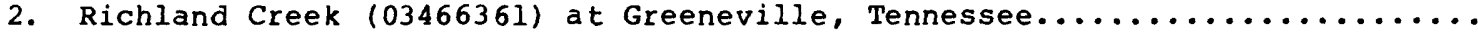

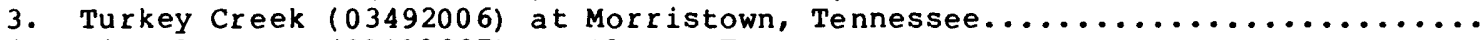

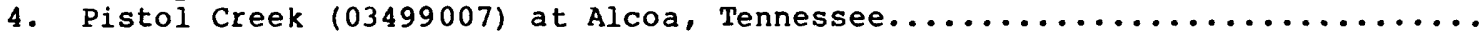

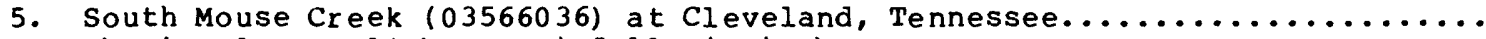

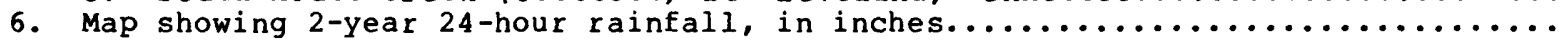
7-14. Graphs showing:

7. Percent change in urban flood discharge resulting from errors in computing drainage area, percentage

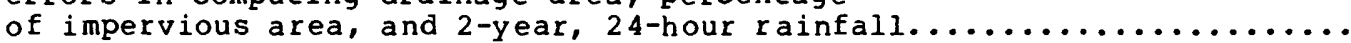

8. Relation of 2-year urban flood discharge to drainage drainage area, percentage of impervious area,

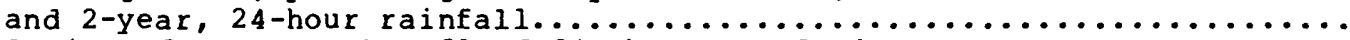

9. Relation of 5 -year urban flood discharge to drainage area, percentage of impervious area, and

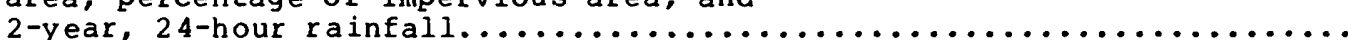

10. Relation of 10-year urban flood discharge to drainage area, percentage of impervious area and 2-year,

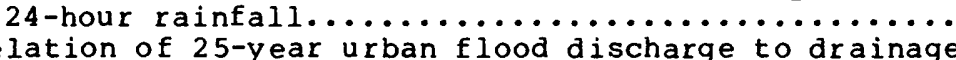

11. Relation of $25-y e a r$ urban flood discharge to drainag,
area, percentage of impervious area, and 2-year,

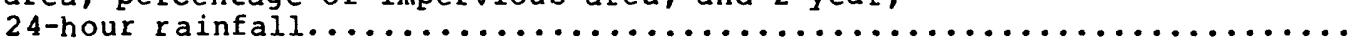

12. Relation of 50-year urban flood discharge to drainage area, percentage of impervious area, and 2-year,

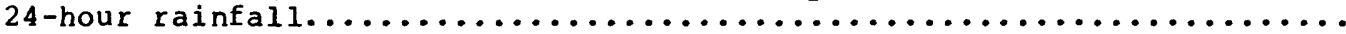

13. Relation of 100 -year urban flood discharge to drainage area, percentage of impervious area, and 2-year,

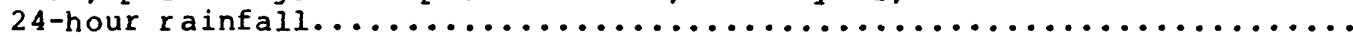

14. Flood-frequency curve for example computation....................

\section{TABLES}

Table 1. Rainfall-runoff model parameters and variables and their application

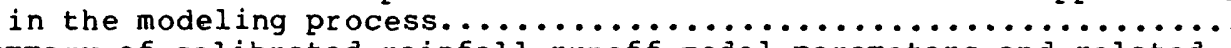

2. Summary of calibrated rainfali-runof model parameters and related

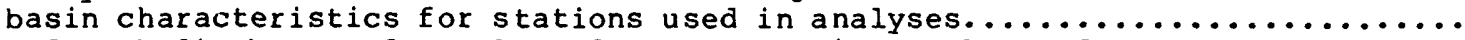

3. Flood peak discharges for selected recurrence intervals, and

parameters used to estimate synthetic floods for urban streams.............

\section{Conversion Factors}

For readers who may prefer to use the International System of Units (SI) $r$ ather than the inch-pound units used herein, the conversion factors are listed below:

\section{Multiply}

inch (in.)

inch per hour (in/h)

mile (mi)

square mile $\left(\mathrm{mi}^{2}\right)$

foot per mile ( $\mathrm{ft} / \mathrm{mi}$ )

cubic foot per second ( $\mathrm{ft}^{3} / \mathrm{s}$ )
BY
2.540
2.540
1.609
2.590
0.189
0.0283

To obtain

centimeter (cm) centimeter per hour $(\mathrm{cm} / \mathrm{h})$ kilometer ( $\mathrm{km})$ square kilometer $\left(\mathrm{km}^{2}\right)$ meter per kilometer (m/km) cubic meter per second $\left(m^{3} / s\right)$ 


\title{
SYNTHESIZED FLOOD FREQUENCY FOR SMALL URBAN STREAMS IN TENNESSEE
}

\author{
Clarence $\mathrm{H}$. Robbins
}

\begin{abstract}
Engineers involved in bridge, culvert, and highway design often need to know the magnitude and frequency of flood discharge from small streams where the drainage basin is urbanized. The results of a 6-year study by the U.S. Geological Survey provide methods for estimating flood magnitudes for selected frequencies on small streams draining urban areas in Tennessee.
\end{abstract}

A total of 22 rainfall-runoff sites located in basins with drainage areas of 0.21 to 24.3 square miles in size and in municipalities with populations between 5,000 and 100,000 were used to derive regionalized flood-frequency equations. Impervious area, measured from recent aerial photographs, ranged between 4.7 percent and 74.0 percent of the basin.

The equations were derived by multiple regression analyses of synthetic floodfrequency estimates, derived from a rainfallrunoff modeling procedure, versus physical basin characteristics and a precipitation factor. These equations can be used to estimate the magnitude of future floods with recurrence intervals of 2 to 100 years on ungaged urbanized streams in Tennessee. One equation for each recurrence interval applies statewide. Flood-frequency estimates for stations used in the analyses and example computations demonstrating application of the regression equations to urban streams in Tennessee are given in the report.

\section{INTRODUCTION}

Engineers involved in bridge, culvert, and highway design often need to know the magnitude and frequency of annual peak discharge from small streams draining urban areas. City planners also need this information for flood insurance studies and for proper flood-plain management and development.

The purpose of this report is to provide equations for estimating the magnitude and frequency of annual floods along urban streams in Tennessee with drainage areas from 0.21 to $24.3 \mathrm{mi}^{2}$. However, these equations do not apply to streams where the magnitude of peak flow is affected significantly by temporary in-channel storage or overbank detention storage. The results presented in this report consist of equations derived by regression analysis of synthetic estimates of 'T-year (annual) floods versus physical basin characteristics and a precipitation factor.

Prior to this statewide urban hydrology study, methods of estimating the magnitude and frequency of floods in the metropolitan areas of Nashville and Memphis were derived by Wibben (1976) and Neely (1984), respectively. Estimating methods for rural basins statewide were derived by Randolph and Gamble (1976). This study extends the previous urban studies and provides methods of estimating flood magnitudes and frequencies for urban areas statewide. The above methods for Memphis and Nashville should be used for those cities. Wibben (1976) indicated that the T-year floods from the gaged urban basins in Nashville were not significantly larger than those from rural basins. Consequently, regional equations for estimating peak $r$ unoff from rural basins (Randolph and Gamble, 1976) should be reliable estimators of $\mathrm{T}-y$ ear floods from urban basins in Nashville within the size and development $r$ ange of $h$ is study.

The data for this study were collected under a cooperative program with the Tennessee Department of Transportation and the Federal Highway Administration. Appreciation is expressed to the Tennessee Department of Transportation for providing aerial photographs of the urban basins in this study.

The relation of flood-peak magnitude to the probability of occurrence, or recurrence interval, is referred to in this report as a flood-frequency relation. As applied to annual floods, recurrence interval is the average interval of time between exceedances of the indicated flood magnitude. For example, a flood with a 10-year recurrence interval may be expected to be equaled or exceeded on the average of once in 10-years or, stated another way, a flood that has a 1 in 10 chance of occurring in any given year. However, the fact that a flood of this magnitude occurs in any given year does not reduce the probability of a flood of equal or greater magnitude occurring within the same year, or in consecutive years.

\section{METHODS OF STUDY}

Systematic collection of flood hydrograph and concurrent rainfall data in urban areas of Tennessee began for this study in 1977 on 22 selected streams (fig. 1). Each 


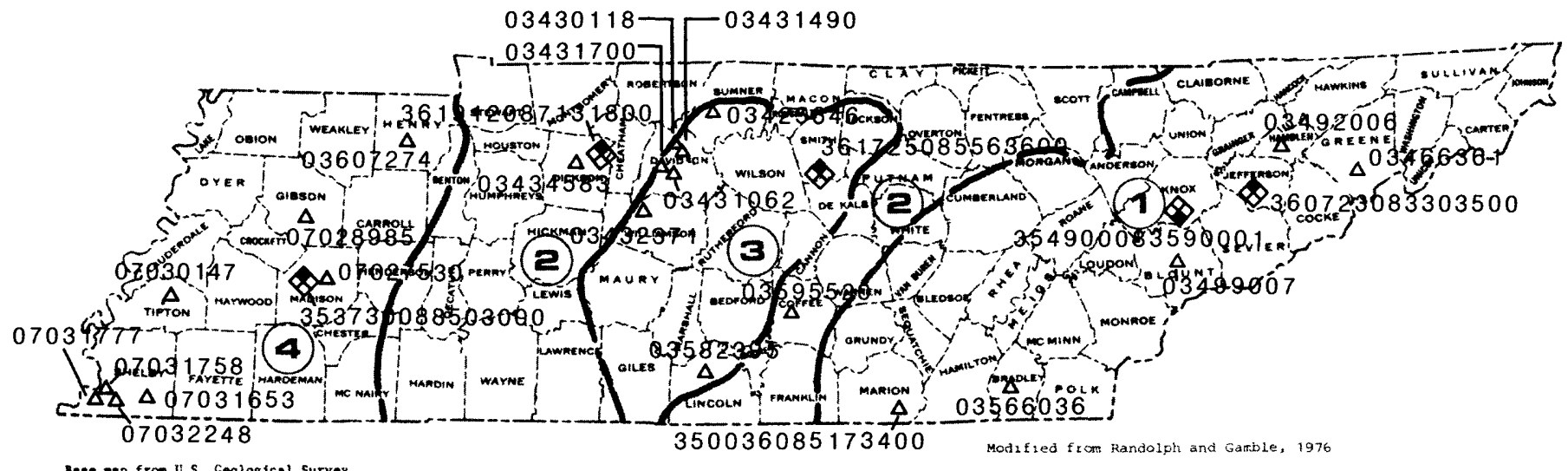

sese anp from V.s. Ceological Survey
U.s. base tap, $i: 2,500,000$

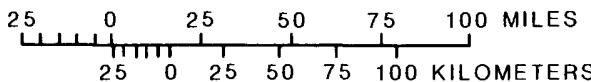

EXPLANATION

03431490

$\Delta$ Urban rainfall-runoff site and number

354900083590001

Long-term rainfall station and number

360723083303500

Q Evaporation station and number

Hydrologic area boundary

(3) Hydrologic area number

Figure 1.-- Location of gaging stations.

of the four hydrologic areas in Tennessee, as defined by Randolph and Gamble (1976), were represented. The length of record of observed data for the 22 stations used in the study ranges from 4 to 8 years.

Reliability of flood-frequency estimates computed from observed annual floods is primarily dependent upon the length of record. For all stations used in this study, the length of record was too short to produce reliable estimates from the observed data. Therefore, the observed data were used to calibrate a rainfall-runoff model (Dawdy and others, 1972), and synthetic flood-frequency estimates were derived using a map-model method described by Lichty and Liscum (1978).

The data used to calibrate the rainfallrunoff model were daily rainfall and panevaporation, and unit rainfall and discharge for storm periods. Also, percentage of impervious area, measured from aerial photographs of each basin, was used. Data from four U. S. Weather Bureau evaporation stations were used in model calibration (fig. 1). The proximity of the urban rainfalirunoff site to the evaporation station determined which evaporation station was used.
Between 25 and 60 storms were used for calibrating each of the 22 basins. Some storms were deleted from the calibration procedure because of station equipment malfunction, unacceptable timing of flood peak and rainfall, or rainfall inadequately distributed over the basin.

\section{Rainfall-Runoff Model}

The rainfall-runoff model developed by Dawdy and others (1972) and modified by Carrigan (1973) uses point rainfall and daily potential evapotranspiration data to predict flood volumes and peak rates of runoff for small drainage basins. The model deals with three components of the hydrologic cycle; that is, antecedent moisture, infiltration, and surface-runoff routing.

The antecedent-moisture component determines the initial infiltration rate for a storm. Input to this component is daily rainfall and pan-evaporation, and the output is the amount of base-moisture storage (BMS) and infiltrated surface-moisture storage (SMS). 
The infiltration component uses the Philip (1954) equation, which is believed to be a somewhat better approximation to the differential equation for unsaturated flow than the classical Horton (1940) exponentialdecay-infiltration equation. Input to the infiltration component is storm rainfall, base-moisture storage (BMS), and infiltrated surface-moisture storage (SMS). The output from this component is the amount of storm rainfall that infiltrates the soil and the amount of storm rainfall that becomes rainfall excess.

Surface-runoff routing, the third component, is based on a modification of the Clark (1945) instantaneous unit hydrograph. First, the rainfall excess is converted into a triangular translation hydrograph representing the effects of varying travel times in the basin. Then successive flow rates of the translation hydrograph are attenuated by routing through linear storage.

The two parameters used to define the translation hydrograph, which is based on an isosceles triangle, are TC and TP/TC. A linear reservoir routing coefficient (KSW) defines the slope of the recession limb of the hydrograph. The time base (duration) of the triangular translation hydrograph is ${ }^{\prime} \mathrm{C}$, and the ratio TP/TC defines the relative time to peak of the translation hydrograph.

The rainfall-runoff model parameters and variables and their application in the modeling process are summarized in table 1 . For a more complete description of the model, see the report by Dawdy and others (1972).

\section{Model Calibration}

Calibration of the rainfall-runoff model for a basin involves an optimization procedure to adjust parameter values to improve the comparison between observed and simulated runoff. The comparison is made by an objective function, which is based on the sum of the squared deviations of the logarithms of peak flow, storm volumes, or some combination of both. Starting values of the parameters (table 1) are computed or estimated, and maximum and minimum parameter limits are set. Observed rainfall and pan-evaporation data are used to generate a streamflow sequence that is compared with the observed streamflow record.

Three separate phases of the calibration optimize on three different objective functions. During phase one, direct runoff volumes are used in the objective function, and parameters pertaining to the antecedent moisture and infiltration components of the model are adjusted. In phase two (the surface-runoff routing phase), peak flows are used in the objective function, and the hydrograph shape parameters are optimized. Volumes routed are scaled to the observed direct runoff volumes to reduce errors introduced by rainfall data and rainfall excess computations. In phase three, peak flows are again used in the objective function while parameters affecting the moisture-accounting and infiltration components are adjusted.

Impervious area (in percent) is also used as an input to the model. The impervious area is assumed to be uniformly distributed throughout the basin and is assumed to be capable of storing 0.05 inch of precipitation. All precipitation in excess of 0.05 inch that falls on the impervious area is assumed to become direct runofr.

\section{Synthetic Flood Data}

Calibrated model parameters were used in a generalized synthetic flood-frequency relation to estimate flood magnitudes for each of the 22 gaging stations (fig. 1). The procedures for estimating flood magnitudes for 2-, 25-, and 100-year recurrence intervals are described by Lichty and Liscum (1978). The calibrated parameters are listed in table 2 of this report. Climatic factors applicable to site locations in Tennessee were taken from figures 5,6 , and 7 in the report by Lichty and Liscum (1978).

The map-model method developed by Lichty and Liscum (1978) applies to a six-state area in the eastern United States. The maps of this area were based on the results of regression analysis of synthetic floodfrequency estimates derived by using 36 longterm rainfall stations. Four of the longterm rainfall stations used by Lichty and Liscum (1978) are in Tennessee.

Synthetic flood magnitudes also were obtained for four of the urban basins by a direct application of the rainfall-runoffmodel using long-term rainfall records and pan-evaporation data. The four basins used were: Richland Creek (03466361) at Greeneville, Tenn., Turkey Creek (03492006) at Morristown, Tenn., Pistol Creek (03499007) at Alcoa, Tenn., and South Mouse Creek (03566036) at Cleveland, Tenn. Calibrated model parameters were used with long-term rainfall records collected by the National Weather Service at Knoxville for the period 1890 to 1983 and pan-evaporation data at Jefferson City for the period 1944 to 1983 (fig. I). The pan-evaporation record was shorter than the rainfall record, thus part of the pan-evaporation record (1890 to 1943) was synthesized using existing data (1944 to 1983) to produce a comparable period of record. The 93 years of rainfall and panevaporation data and the calibrated model parameters (table 2) were then used as input for the model to synthesize 93 annual peak discharges for the four urban basins in east Tennessee. The synthetic annual peaks were then used in a log-Pearson Type III analysis to develop a flood-frequency curve for each of the four stations. 
Table 1.--Rainfal1-runoff model parameters and variables and their application in the modeling process

[Modified from Lichty and Liscum (1978)]

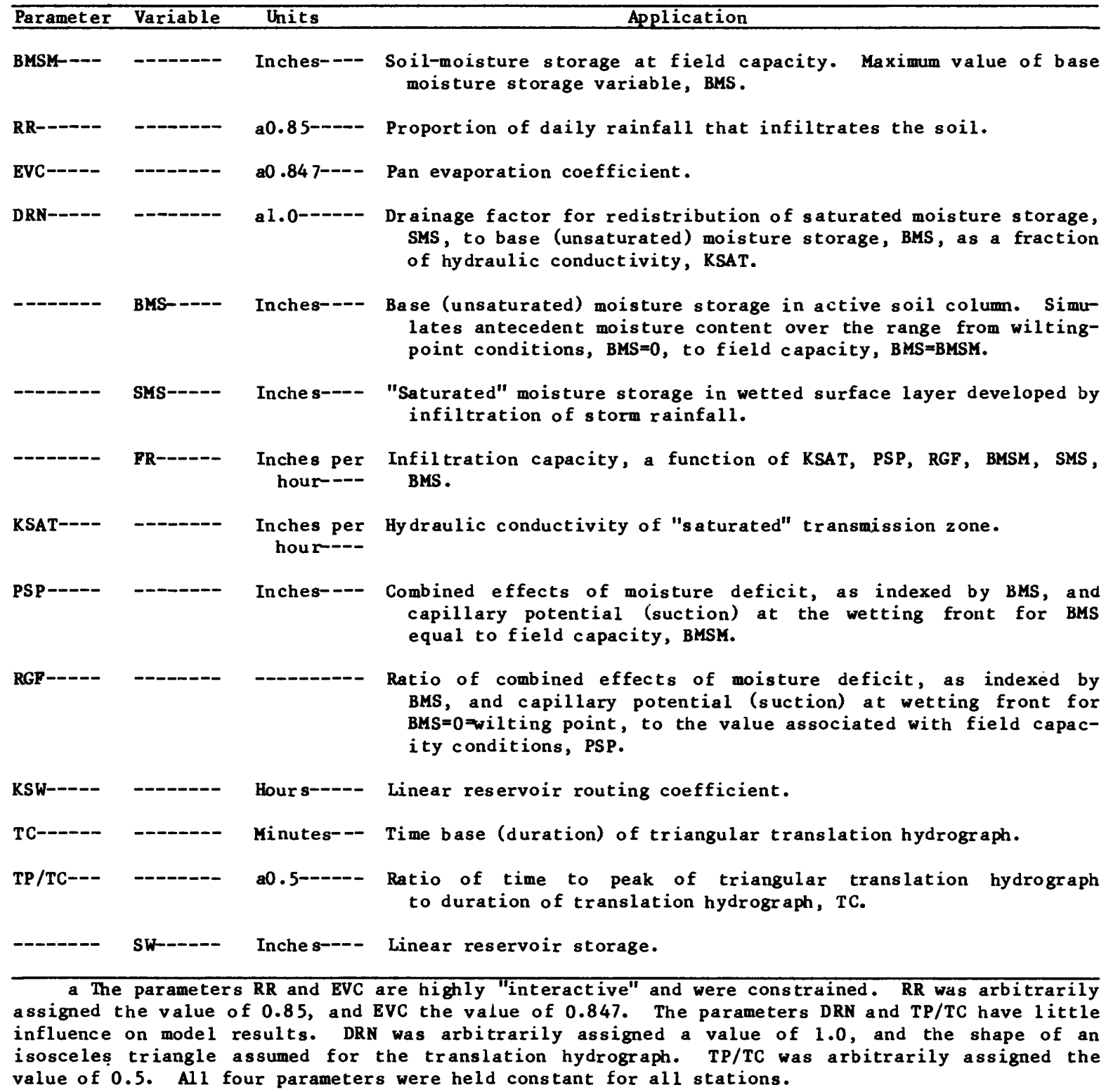

Results of the above two methods along with estimated rural flood magnitudes for the four east Tennessee urban basins are illustrated in figures $2,3,4$, and 5 . Comparison of the results indicates that the long-term rainfall method and the map-model method give flood magnitudes that are similar. Differences between the two methods are mainly due to differences in skew. It is assumed that this comparison for other stations in Tennessee would be similar, therefore, the mapmodel method was used to generate floodfrequency curves for all of the 22 gaging stations. The relation between the urban frequency curves and the rural frequency curve shows the typical affects of urbanization upon the magnitude of floods. However, in figure 4 the rural curve is higher than the urban curve, which is probably due to the location of the urban development within the basin.

Lichty and Liscum (1978) demonstrated that the map-model procedure has a tendency to underestimate (bias) higher recurrenceinterval floods in rural areas. They indicate that the estimates are 19 percent low at the 25-year recurrence interval, and 29 
Table 2.--Summary of calibrated rainfall-runoff model parameters and related basin characteristics tor stations used in analyses

[The model variables $D R N=1.00, R R=0.85, E V C=0.847$, and $T P / T C=0.50$ are constant for all 8 tations]

\begin{tabular}{|c|c|c|c|c|c|c|c|c|c|c|c|c|}
\hline $\begin{array}{l}\text { Station } \\
\text { No. }\end{array}$ & Station name & $\begin{array}{c}\text { Drainage } \\
\text { area } \\
\left(\mathrm{mi}^{2}\right) \\
\text { (A) }\end{array}$ & $\begin{array}{c}\text { Channe } 1 \\
\text { s lope } \\
\text { (ft/mi) } \\
\text { (CS) }\end{array}$ & $\begin{array}{l}\text { Channe } 1 \\
\text { length, } \\
\text { (mi) } \\
\text { (cL) }\end{array}$ & $\begin{array}{c}\text { Basin } \\
\text { develop- } \\
\text { ment } \\
\text { factor } \\
\text { (BDF) }\end{array}$ & $\begin{array}{l}\text { Imper- } \\
\text { vious } \\
\text { area } \\
\text { (percent) } \\
\end{array}$ & $\begin{array}{c}\text { PSP } \\
\text { (in.) }\end{array}$ & $\begin{array}{c}\text { KSAT } \\
(\mathrm{in} / \mathrm{h}) \\
\end{array}$ & RGF & $\begin{array}{l}\text { BMSM } \\
\text { (in.) }\end{array}$ & $\begin{array}{l}\text { KSW } \\
(\mathrm{h})\end{array}$ & $\begin{array}{l}\text { TC } \\
\text { (min) } \\
\end{array}$ \\
\hline 03425646 & $\begin{array}{l}\text { Town Creek at Maple } \\
\text { Street at Gallatin, } \\
\text { Tenn. }\end{array}$ & 5.00 & 37.6 & 5.07 & 2 & 9.34 & 1.646 & 0.074 & 24.884 & 4.398 & 1.628 & 115.0 \\
\hline 03430118 & $\begin{array}{l}\text { McCrory Creek at } \\
\text { Ironwood Drive } \\
\text { at Donelson, Tenn. }\end{array}$ & 7.31 & 26.8 & 4.48 & 0 & 5.74 & 1.804 & .039 & 20.034 & 5.774 & 2.369 & 118.8 \\
\hline 03431062 & $\begin{array}{l}\text { Mill Creek Tributary at } \\
\text { Glenrose Avenue at } \\
\text { Nashville, Tenn. }\end{array}$ & 1.17 & 78.5 & 1.61 & 0 & 22.81 & 6.426 & .176 & 19.412 & 4.278 & .501 & 27.0 \\
\hline 03431490 & $\begin{array}{l}\text { Pages Branch at Avon- } \\
\text { dale, Tenn. }\end{array}$ & 2.01 & 97.1 & 2.27 & 0 & 14.97 & 2.343 & .105 & 24.452 & 4.607 & .928 & 66.0 \\
\hline 03431700 & $\begin{array}{l}\text { Richland Creek at } \\
\text { Charlotte Avenue }\end{array}$ & 24.30 & 33.0 & 7.90 & 2 & 26.11 & 2.481 & .087 & 24.087 & 5.412 & 1.685 & 190.0 \\
\hline 03432371 & $\begin{array}{l}\text { at Na shville, Tenn. } \\
\text { Harpeth River Tributary } \\
\text { at Franklin, Tenn. }\end{array}$ & 1.81 & 74.9 & 2.49 & 0 & 4.68 & 5.336 & .191 & 11.088 & 4.897 & 1.371 & 66.0 \\
\hline 03434583 & $\begin{array}{c}\text { Jones Creek Tributary } \\
\text { at Dickson, Tenn. }\end{array}$ & 2.29 & 68.9 & 1.98 & 1 & 14.79 & 2.082 & .056 & 7.880 & 4.774 & 1.136 & 41.4 \\
\hline 03466361 & $\begin{array}{l}\text { Richland Creek at } \\
\text { Greeneville, Tenn. }\end{array}$ & 3.48 & 76.3 & 3.09 & 5 & 21.54 & 4.241 & .133 & 39.847 & 8.809 & .607 & 63.8 \\
\hline 03492006 & $\begin{array}{l}\text { Turkey Creek at } \\
\text { Morristown, Tenn. }\end{array}$ & 5.09 & 53.8 & 4.16 & 5 & 13.07 & 4.839 & .140 & 39.761 & 10.390 & .846 & 62.0 \\
\hline 03499007 & $\begin{array}{l}\text { Pistol Creek at Al coa, } \\
\text { Tenn. }\end{array}$ & 15.70 & 25.8 & 8.27 & 3 & 11.60 & 4.433 & .129 & 33.871 & 4.317 & 4.516 & 148.0 \\
\hline 03566036 & $\begin{array}{c}\text { South Mouse Creek at } \\
\text { Cleveland, Tenn. }\end{array}$ & 7.31 & 24.3 & 4.07 & 3 & 17.35 & 5.109 & .179 & 34.817 & 3.110 & .975 & 75.0 \\
\hline 03582395 & $\begin{array}{l}\text { Tanyard Branch at } \\
\text { Fayetteville, Tenn. }\end{array}$ & .47 & 184.0 & .65 & 5 & 48.30 & 5.835 & .245 & 14.865 & 2.337 & .290 & 10.4 \\
\hline 03595520 & $\begin{array}{c}\text { Grindstone Hollow Creek } \\
\text { at Manchester, Tenn. }\end{array}$ & 2.11 & 28.2 & 2.60 & 0 & 21.50 & 3.082 & .071 & 23.212 & 7.977 & 2.512 & 72.0 \\
\hline 03607274 & $\begin{array}{l}\text { Bailey Fork Creek } \\
\text { Tributary at Paris, } \\
\text { Tenn. }\end{array}$ & 1.04 & 57.1 & 2.34 & 1 & 15.60 & 2.774 & .066 & 12.013 & 1.116 & 1.080 & 43.4 \\
\hline 07027530 & $\begin{array}{l}\text { South Fork Forked Deer } \\
\text { River Tributary at } \\
\text { Jackson, Tenn. }\end{array}$ & .98 & 54.9 & 1.64 & 8 & 39.86 & 2.350 & .287 & 23.935 & 1.860 & .501 & 17.1 \\
\hline 07028985 & $\begin{array}{l}\text { Middle Fork Forked Deer } \\
\text { River Tributary at } \\
\text { Humboldt, Tenn. }\end{array}$ & 2.12 & 26.3 & 2.64 & 0 & 25.40 & 2.235 & .054 & 17.065 & 4.536 & 1.238 & 72.8 \\
\hline 07030147 & $\begin{array}{l}\text { Town Creek Tributary } \\
\text { at Covington, Tenn. }\end{array}$ & .75 & 42.7 & 1.70 & 0 & 19.30 & 1.039 & .042 & 16.158 & 1.158 & .608 & 43.0 \\
\hline 07031653 & $\begin{array}{l}\text { Wolf River Tributary } \\
\text { at Willey Road at } \\
\text { Germantown, Tenn. }\end{array}$ & .21 & 68.6 & .76 & 3 & 32.00 & 1.170 & .065 & 29.100 & 6.500 & .577 & 17.7 \\
\hline 07031758 & $\begin{array}{l}\text { Cy press Creek at Broad } \\
\text { Street at Memphis, } \\
\text { Tenn. }\end{array}$ & 4.97 & 19.1 & 4.66 & 10 & 57.77 & 7.968 & .149 & 24.681 & 7.476 & .519 & 40.5 \\
\hline 07031777 & $\begin{array}{l}\text { Lick Creek at Dickson } \\
\text { Street at Memphis, } \\
\text { Tenn. }\end{array}$ & 2.96 & 22.0 & 3.28 & 9 & 46.00 & 1.810 & .085 & 16.300 & 2.640 & .520 & 43.0 \\
\hline 07032248 & $\begin{array}{l}\text { Cane Creek at East } \\
\text { Person Street } \\
\text { at Memphis, Tenn. }\end{array}$ & 4.98 & 24.7 & 3.11 & 10 & 74.00 & 1.280 & .079 & 5.610 & 1.120 & .447 & 56.0 \\
\hline $\begin{array}{l}3500360- \\
85173400\end{array}$ & $\begin{array}{l}\text { South Fork Dobbs } \\
\text { Branch at Chattanooga, } \\
\text { Tenn. }\end{array}$ & 1.12 & 111.3 & 1.41 & 10 & 28.84 & 2.156 & .057 & 6.990 & 3.194 & 1.018 & 60.0 \\
\hline
\end{tabular}




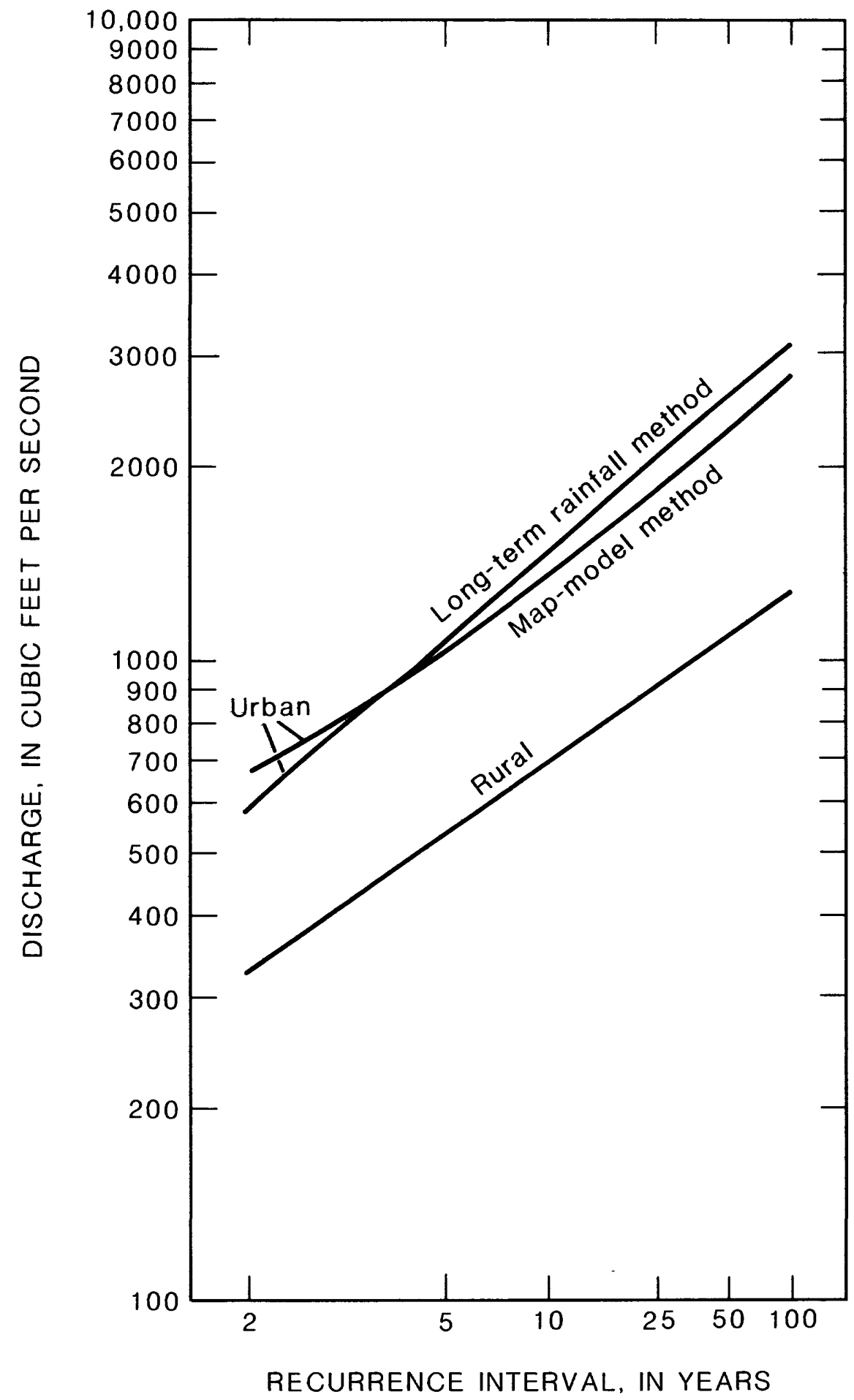

Figure 2.-- Flood frequency curves representing different estimating methods for Richland Creek (03466361) at Greeneville, Tennessee. 


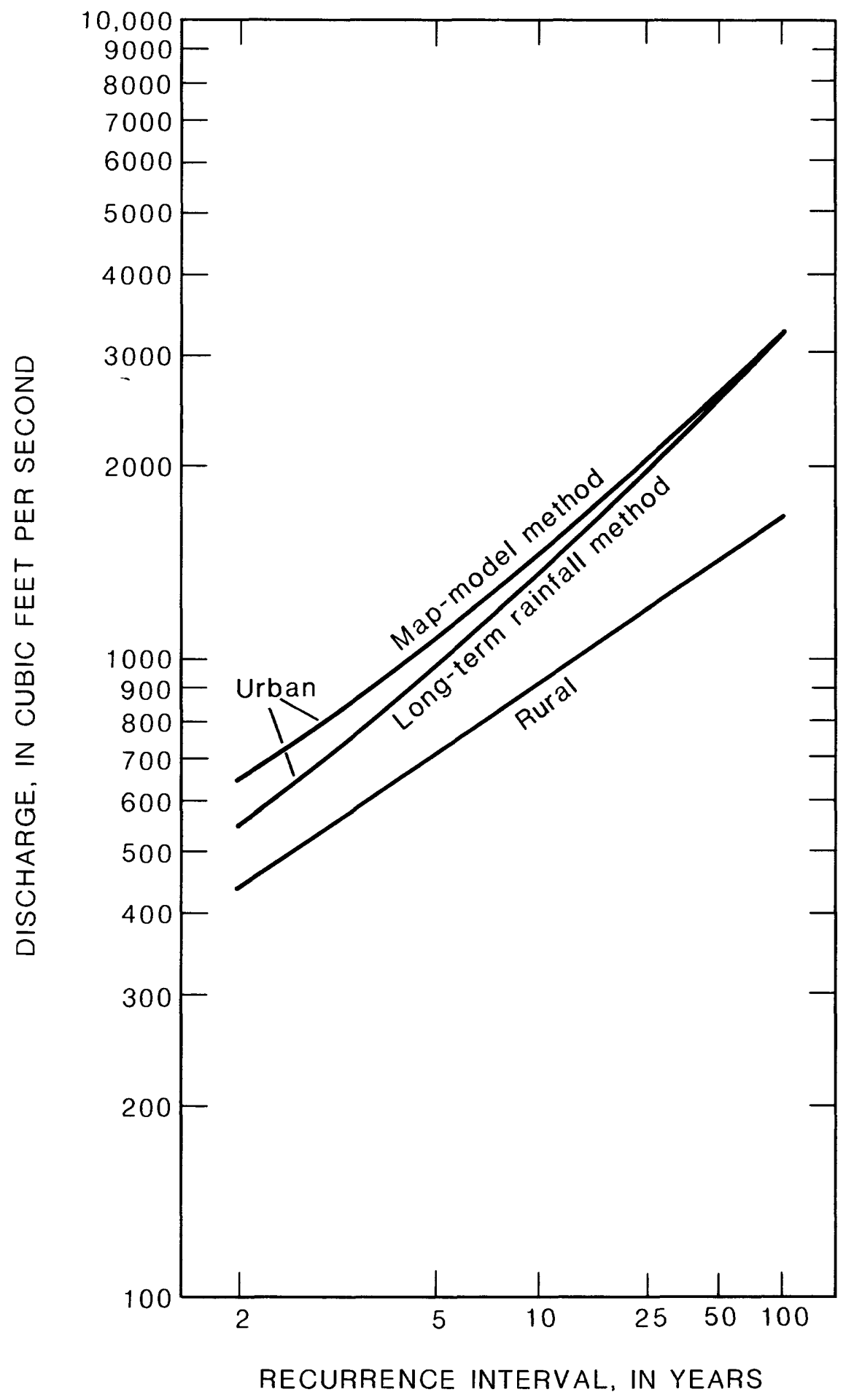

Figure 3.-- Flood frequency curves representing different estimating methods for Turkey Creek (03492006) at Morristown, Tennessee. 


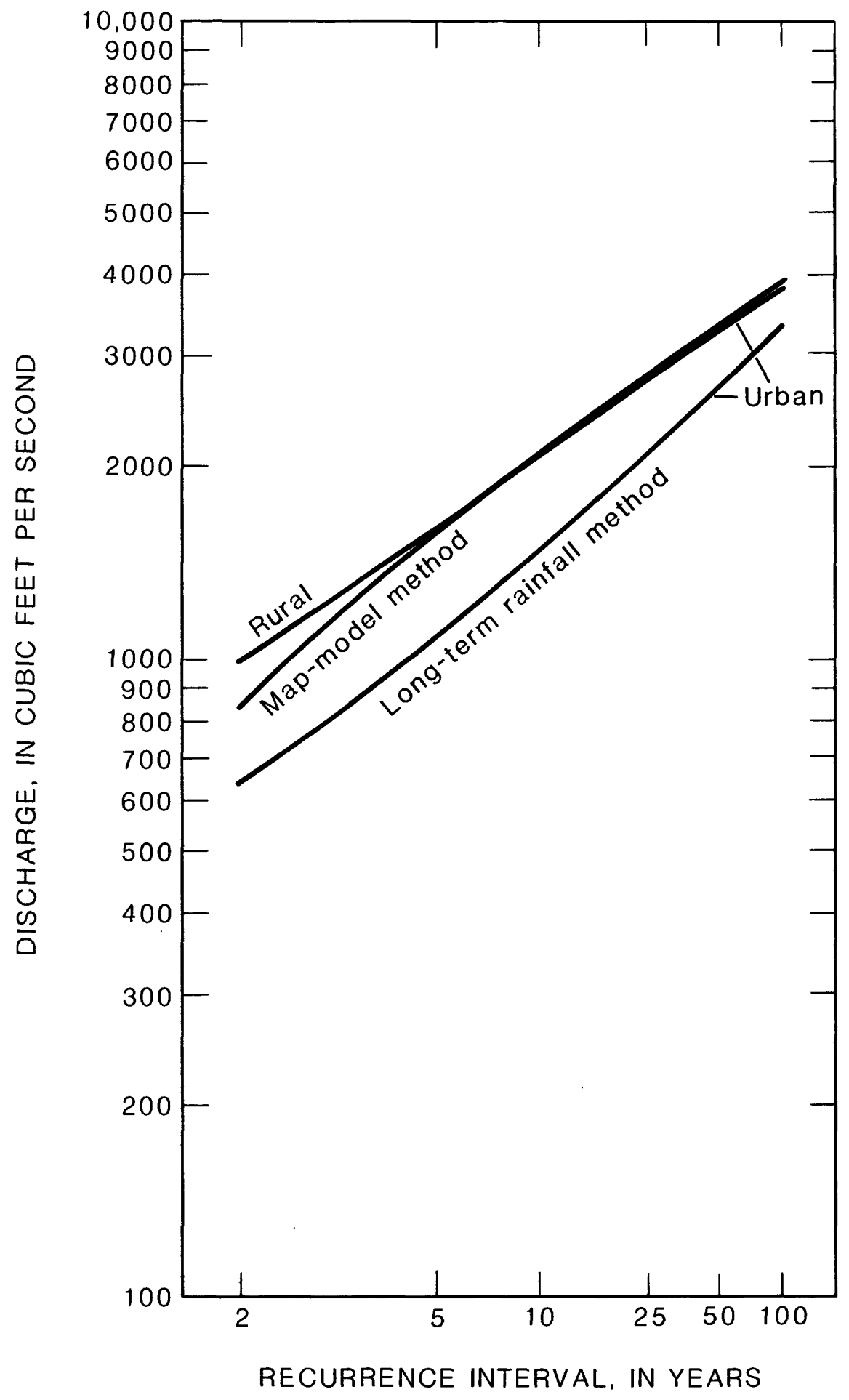

Figure 4.-- Flood frequency curves representing different estimating methods for Pistol Creek (03499007) at Alcoa, Tennessee. 


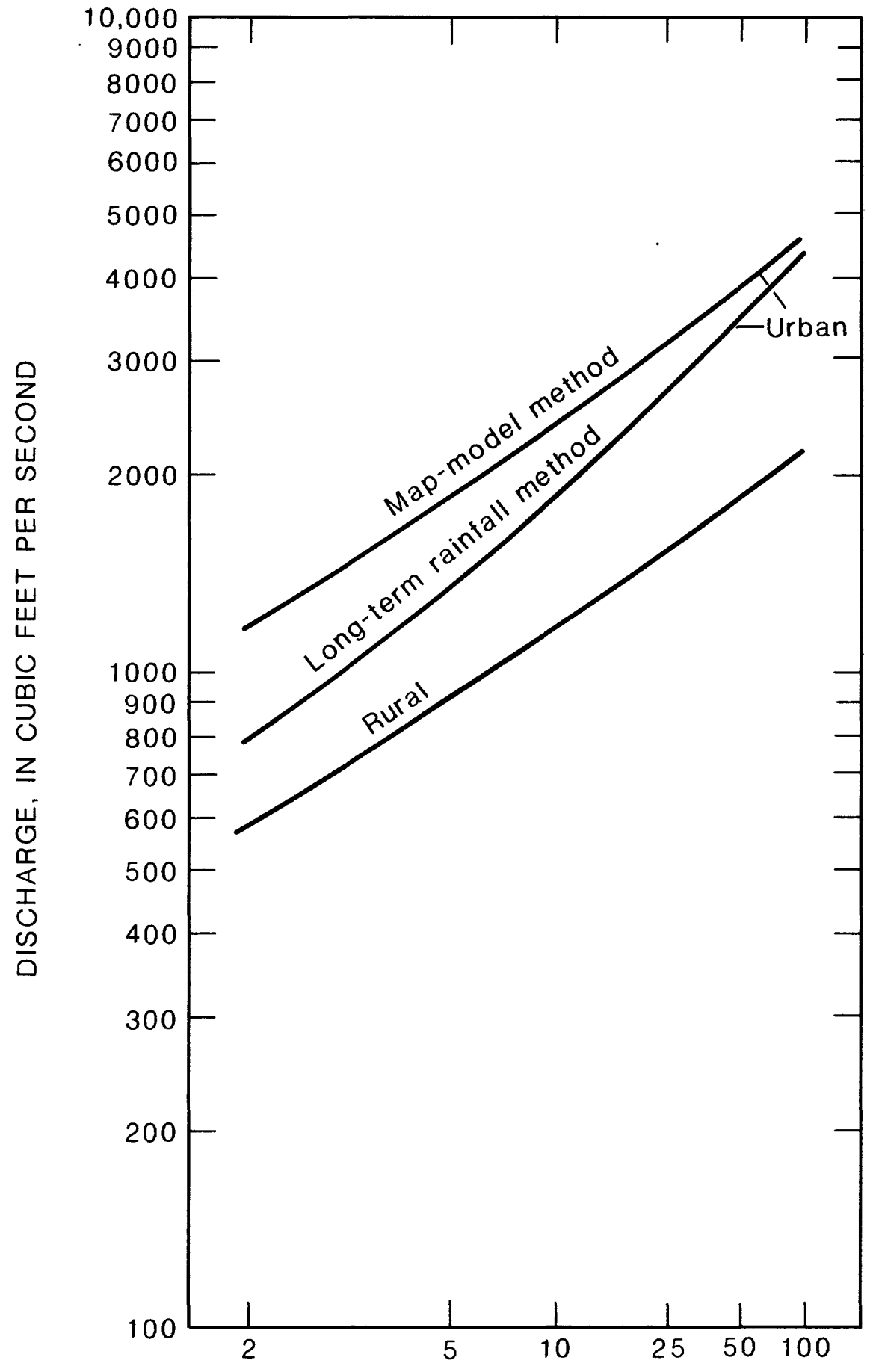

RECURRENCE INTERVAL, IN YEARS

Figure 5.-- Flood frequency curves representing different estimating methods for South Mouse Creek (03566036) at Cleveland, Tennessee. 
percent low at the 100-year recurrence interval. Five possible reasons for underestimation are given by Lichty and Liscum (1978): two are related to the structure of the rainfall-runoff model, two are associated with possible deficiencies in data used for annual-flood synthesis, and one is due to a loss of variance associated with the smoothing effect of the model.

The bias adjustment was not applied in this study for several reasons. First, a comparison of the map-model frequency curves with no bias adjustment to the long-term rainfall synthesized curves (see figures 2-5) for four randomly selected stations indicates reasonable agreement at high recurrence intervals. For instance, for the four sites the maximum difference of the 100-year floods occurs at station 03499007 (fig. 4), where the map-model estimate is 18 percent greater than the long-term rainfall estimate. Application of the bias adjustment would in all four cases, increase the difference between the two curves.

Secondly, it is generally conceptualized that an urban flood-frequency curve should have a flatter slope than an equivalent rural flood-frequency curve. The presently used rural estimates are taken from Randolph and Gamble (1976) and are shown for comparison on figures 2-5. In each case, the map-model curve, unadjusted for bias, is either nearly parallel to, or is steeper than the equivalent rural curve. Application of the bias adjustment would cause an even greater deviation from the conceptual relation of these curves than is already indicated.

Third, and finally, oral and written communication (1984) with Lichty indicates an uncertainty as to the validity of the bias adjustment for urban streams. The bias adjustments were developed for rural streams by comparing "observed" estimates to mapmodel estimates. Lichty and Liscum (1978) assumed the observed estimates were from an unbiased time sample, but the average length of observed record was only 13 years and therefore subject to considerable timesampling error at the high recurrence intervals. They state "...the map-model estimates are apparently biased...." thus indicating a degree of uncertainty. Considering all of the above reasons and especially the conceptual aspects, it was decided to not apply the bias adjustments to the results of this study.

\section{Estimates of T-Year (Annual) Floods}

The procedure to estimate T-year (annual) floods required computation of an infiltration factor (F), in inches per hour, and lag time (L), in hours. The infiltration factor (F) and lag time (I) are computed by the following equations:

$F=\operatorname{KSAT}[1.0+0.5 \operatorname{PSP}(0.15 \mathrm{RGF}+0.85)]$ and lag time (L) by:

$$
L=K S W+0.5(T C / 60)
$$

Definitions of KSAT, PSP, RGF, KSW, and TC are listed in table 1 and their values for each station are 1 isted in table 2 .

Infiltration factors are related to the surface material in a basin. For example, Harpeth River Tributary (03432371) at Franklin, Tenn., is in an area of soluble limestone and the infiltration factor is 1.47 inches per hour, whereas Jones Creek Tributary (03434583) at Dickson, Tenn., is underlain with sanay clay and the infiltration factor is 0.17 inch per hour. Values of $F$ and $L$ for the 22 stations used in this study are given in table 3 .

Estimates of the 2-, 25-, and 100-year recurrence-interval synthetic flood magnitudes were then computed for each of the 22 stations using the equation from Lichty and Li scum (1978) as follows:

$$
\hat{Q}_{i}=C_{i} L-0.69_{F} f\left(C_{i}\right)\left[1.0+I\left(\frac{g\left(C_{i}\right)}{F^{f}\left(C_{i}\right)}-1.0\right)\right](A)
$$

where $\hat{Q}_{i}$ is the flood magnitude estimate for the corresponding recurrence interval $(i=2,25$, and 100 years),

$c_{i}$ is the climatic factors for the site location and recurrence interval ( $f$ igures 5,6 , and 7 in the report by Lichty and Liscum, 1978)

$A$ is the drainage area in square miles,

L is the lag time computed from equation (2),

$F$ is the infiltration factor computed from equation (1).

I is the percentage of total surface area in the drainage basin that is impervious, and

$f\left(c_{i}\right)=0.41 \log c_{i}-1.39$

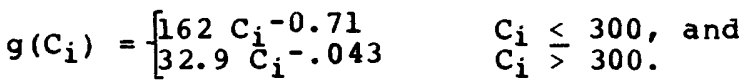

The urban flood estimates for the 2-, 25-, and 100-year recurrence intervals were plotted on log-probability paper for each of the 22 stations. These points plotted as nearly straight lines. Therefore, flood estimates for the 5-, 10-, and 50-year recurrence intervals were determined graphically from the plots. The estimated flood magnitudes for selected recurrence intervals are given in table 3 .

\section{ANALYTICAL TECHNIQUES}

\section{Approach and Variables}

standard multiple linear regression techniques were used to develop equations for estimating the 2-, 5-, 10-, 25-, 50-, and 100-year flood peaks from $n$ ine basin and 
Table 3.--Flood peak discharges for selected recurrence intervals, and parameters used to estimate synthetic flood peaks for urban streams

[Rural discharges were estimated with method in report by Randolph and Gamble (1976); urban discharges were estimated with method in report by Lichty and Liscum (1978)]

\begin{tabular}{|c|c|c|c|c|c|c|c|c|c|c|}
\hline \multirow{2}{*}{$\begin{array}{c}\text { Station } \\
\text { No. }\end{array}$} & \multirow[b]{2}{*}{ Station name } & \multirow{2}{*}{$\begin{array}{l}\text { Type of } \\
\text { estimate }\end{array}$} & \multirow{2}{*}{$\begin{array}{l}\text { Mode } 1 \\
\operatorname{lag} t \text { ime } \\
\text { (L) } \\
\text { (hours) }\end{array}$} & \multirow{2}{*}{$\begin{array}{c}\text { Model } \\
\text { infiltration } \\
\text { factor } \\
\text { (F) } \\
\text { (inches/hour) }\end{array}$} & \multicolumn{6}{|c|}{$\begin{array}{l}\text { Flood peak discharges } \\
\left(\mathrm{ft}^{3} / \mathrm{s}\right)\end{array}$} \\
\hline & & & & & 2 & 5 & 10 & 25 & 50 & 100 \\
\hline 03425646 & $\begin{array}{l}\text { Town Creek at Maple } \\
\text { Street at Gallatin, } \\
\text { Tenn. }\end{array}$ & $\begin{array}{l}\text { Urban } \\
\text { Rural } \\
\text { Regression }\end{array}$ & 2.59 & 0.35 & $\begin{array}{r}870 \\
1,040 \\
674\end{array}$ & $\begin{array}{l}1,300 \\
1,640 \\
1,080\end{array}$ & $\begin{array}{l}1,600 \\
2,080 \\
1,370\end{array}$ & $\begin{array}{l}2,000 \\
2,660 \\
1,780\end{array}$ & $\begin{array}{l}2,320 \\
3,110 \\
2,100\end{array}$ & $\begin{array}{l}2,650 \\
3,580 \\
2,440\end{array}$ \\
\hline 03430118 & $\begin{array}{l}\text { McCrory Creek } \\
\text { at Ironwood Drive } \\
\text { at Donelson, Tenn. }\end{array}$ & $\begin{array}{l}\text { Urban } \\
\text { Rural } \\
\text { Regression }\end{array}$ & 3.36 & .17 & $\begin{array}{r}1,330 \\
1,370 \\
765\end{array}$ & $\begin{array}{l}1,920 \\
2,170 \\
1,240\end{array}$ & $\begin{array}{l}2,300 \\
2,740 \\
1,560\end{array}$ & $\begin{array}{l}2,900 \\
3,500 \\
2,050\end{array}$ & $\begin{array}{l}3,210 \\
4,090 \\
2,380\end{array}$ & $\begin{array}{l}3,520 \\
4,700 \\
2,740\end{array}$ \\
\hline 03431062 & $\begin{array}{l}\text { Mill Creek Tributary } \\
\text { at Glenrose Avenue } \\
\text { at Nashville, Tenn. }\end{array}$ & $\begin{array}{l}\text { Urban } \\
\text { Rural } \\
\text { Regression }\end{array}$ & .73 & 2.30 & $\begin{array}{l}380 \\
360 \\
382\end{array}$ & $\begin{array}{l}595 \\
570 \\
575\end{array}$ & $\begin{array}{l}740 \\
730 \\
712\end{array}$ & $\begin{array}{l}930 \\
940 \\
893\end{array}$ & $\begin{array}{l}1,070 \\
1,090 \\
1,050\end{array}$ & $\begin{array}{l}1,200 \\
1,260 \\
1,210\end{array}$ \\
\hline 03431490 & $\begin{array}{l}\text { Pages Branch at Avon- } \\
\text { dale, Tenn. }\end{array}$ & $\begin{array}{l}\text { Urban } \\
\text { Rura } 1 \\
\text { Regression }\end{array}$ & 1.48 & .66 & $\begin{array}{l}450 \\
530 \\
466\end{array}$ & $\begin{array}{l}680 \\
850 \\
717\end{array}$ & $\begin{array}{r}850 \\
1,080 \\
893\end{array}$ & $\begin{array}{l}1,110 \\
1,380 \\
1,140\end{array}$ & $\begin{array}{l}1,250 \\
1,610 \\
1,330\end{array}$ & $\begin{array}{l}1,410 \\
1,860 \\
1,530\end{array}$ \\
\hline 03431700 & $\begin{array}{l}\text { Richland Creek } \\
\text { at Charlotte Avenue } \\
\text { at Nashville, Tenn. }\end{array}$ & $\begin{array}{l}\text { Urban } \\
\text { Rural } \\
\text { Regression }\end{array}$ & 3.27 & .57 & $\begin{array}{l}3,880 \\
3,310 \\
3,840\end{array}$ & $\begin{array}{l}5,650 \\
5,170 \\
5,860\end{array}$ & $\begin{array}{l}6,900 \\
6,500 \\
7,380\end{array}$ & $\begin{array}{l}8,680 \\
8,310 \\
9,200\end{array}$ & $\begin{array}{r}9,700 \\
9,720 \\
10,850\end{array}$ & $\begin{array}{l}10,800 \\
11,150 \\
12,460\end{array}$ \\
\hline 03432371 & $\begin{array}{l}\text { Ha rpeth River Tributary } \\
\text { at Franklin, Tenn. }\end{array}$ & $\begin{array}{l}\text { Urban } \\
\text { Rural } \\
\text { Regression }\end{array}$ & 1.92 & 1.47 & $\begin{array}{l}210 \\
490 \\
262\end{array}$ & $\begin{array}{l}370 \\
790 \\
420\end{array}$ & $\begin{array}{r}480 \\
1,000 \\
524\end{array}$ & $\begin{array}{r}670 \\
1,280 \\
689\end{array}$ & $\begin{array}{r}800 \\
1,500 \\
791\end{array}$ & $\begin{array}{r}950 \\
1,720 \\
903\end{array}$ \\
\hline 03434583 & $\begin{array}{c}\text { Jones Creek Tributary } \\
\text { at Dickson, Tenn. }\end{array}$ & $\begin{array}{l}\text { Urban } \\
\text { Rural } \\
\text { Regression }\end{array}$ & 1.48 & .17 & $\begin{array}{l}820 \\
370 \\
537\end{array}$ & $\begin{array}{r}1,170 \\
640 \\
820\end{array}$ & $\begin{array}{r}1,400 \\
850 \\
1,020\end{array}$ & $\begin{array}{l}1,720 \\
1,120 \\
1,290\end{array}$ & $\begin{array}{l}1,910 \\
1,340 \\
1,500\end{array}$ & $\begin{array}{l}2,130 \\
1,570 \\
1,710\end{array}$ \\
\hline 03466361 & $\begin{array}{l}\text { Richland Creek } \\
\text { at Greeneville, } \\
\text { Tenn. }\end{array}$ & $\begin{array}{l}\text { Urban } \\
\text { Rural } \\
\text { Regression }\end{array}$ & 1.14 & 2.06 & $\begin{array}{l}660 \\
320 \\
555\end{array}$ & $\begin{array}{r}1,060 \\
530 \\
899\end{array}$ & $\begin{array}{r}1,400 \\
680 \\
1,190\end{array}$ & $\begin{array}{r}1,870 \\
900 \\
1,540\end{array}$ & $\begin{array}{l}2,300 \\
1,080 \\
1,920\end{array}$ & $\begin{array}{l}2,750 \\
1,270 \\
2,310\end{array}$ \\
\hline 03492006 & $\begin{array}{l}\text { Turkey Creek at Morris- } \\
\text { town, Tenn. }\end{array}$ & $\begin{array}{l}\text { Urban } \\
\text { Rural } \\
\text { Regression }\end{array}$ & 1.36 & 2.45 & $\begin{array}{l}650 \\
430 \\
608\end{array}$ & $\begin{array}{r}1,100 \\
700 \\
1,000\end{array}$ & $\begin{array}{r}1,480 \\
900 \\
1,320\end{array}$ & $\begin{array}{l}2,050 \\
1,180 \\
1,730\end{array}$ & $\begin{array}{l}2,590 \\
1,410 \\
2,140\end{array}$ & $\begin{array}{l}3,220 \\
1,660 \\
2,550\end{array}$ \\
\hline 03499007 & $\begin{array}{l}\text { Pi stol Creek at Al coa, } \\
\text { Tenn. }\end{array}$ & $\begin{array}{l}\text { Urban } \\
\text { Rural } \\
\text { Regression }\end{array}$ & 5.75 & 1.83 & $\begin{array}{r}840 \\
1,010 \\
1,670\end{array}$ & $\begin{array}{l}1,520 \\
1,600 \\
2,680\end{array}$ & $\begin{array}{l}2,050 \\
2,040 \\
3,440\end{array}$ & $\begin{array}{l}2,750 \\
2,650 \\
4,450\end{array}$ & $\begin{array}{l}3,300 \\
3,160 \\
5,310\end{array}$ & $\begin{array}{l}3,850 \\
3,690 \\
6,180\end{array}$ \\
\hline 03566036 & $\begin{array}{c}\text { South Mouse Creek at } \\
\text { Cl eveland, Tenn. }\end{array}$ & $\begin{array}{l}\text { Urban } \\
\text { Rural } \\
\text { Regression }\end{array}$ & 1.60 & 2.95 & $\begin{array}{r}1,170 \\
570 \\
1,430\end{array}$ & $\begin{array}{r}1,940 \\
910 \\
2,160\end{array}$ & $\begin{array}{l}2,460 \\
1,170 \\
2,680\end{array}$ & $\begin{array}{l}3,010 \\
1,530 \\
3,370\end{array}$ & $\begin{array}{l}3,860 \\
1,830 \\
3,900\end{array}$ & $\begin{array}{l}4,630 \\
2,150 \\
4,430\end{array}$ \\
\hline
\end{tabular}

climatic characteristics. All nine characteristics defined in this report were used in the regression analyses; however, only those that were statistically significant at the 5-percent confidence level are included in the final equations. The nine characteristics are: drainage area, main-channel slope, main-channel length, precipitation factor, basin development factor, percentage of impervious area, lag time, mean annual precipitation, and peak discharge for rural conditions. Definitions of these charac- teristics are as follows:

Drainage area (A) is the contributing drainage area of the basin, in square miles. Main-channel slope (CS) is the slope in feet per mile, determined from the difference in elevation at points 10 and 85 percent of the distance along the main channel from the discharge site to the drainage-basin divide.

Main-channel length $(C L)$ is the distance in miles, from the discharge site to the drainage-basin divide, measured along the main water course. 
Table 3.--Flood peak discharges for selected recurrence intervals, and parameters used to estimate synthetic flood peaks for urban 8 treams--Continued

\begin{tabular}{|c|c|c|c|c|c|c|c|c|c|c|}
\hline \multirow{2}{*}{$\begin{array}{l}\text { Station } \\
\text { No. }\end{array}$} & \multirow[b]{2}{*}{ Station name } & \multirow{2}{*}{$\begin{array}{l}\text { Type of } \\
\text { estimate } \\
\end{array}$} & \multirow{2}{*}{$\begin{array}{l}\text { Model } \\
\text { lag time } \\
\quad(\mathrm{L}) \\
\text { (hours) }\end{array}$} & \multirow{2}{*}{$\begin{array}{c}\text { Model } \\
\text { infiltration } \\
\text { factor } \\
\text { (F) } \\
\text { (inches/hour) }\end{array}$} & \multicolumn{6}{|c|}{$\begin{array}{l}\text { Flood peak discharges } \\
\left(\mathrm{ft}^{3} / \mathrm{s}\right) \\
\text { ated recurrence interval }\end{array}$} \\
\hline & & & & & 2 & 5 & 10 & 25 & 50 & 100 \\
\hline 03582395 & $\begin{array}{l}\text { Tanyard Branch at } \\
\text { Fa yetteville, Tenn. }\end{array}$ & $\begin{array}{l}\text { Urban } \\
\text { Rural } \\
\text { Regression }\end{array}$ & 0.38 & 2.45 & $\begin{array}{l}410 \\
180 \\
333\end{array}$ & $\begin{array}{l}580 \\
300 \\
468\end{array}$ & $\begin{array}{l}690 \\
380 \\
560\end{array}$ & $\begin{array}{l}820 \\
480 \\
676\end{array}$ & $\begin{array}{l}950 \\
570 \\
779\end{array}$ & $\begin{array}{r}1,080 \\
650 \\
878\end{array}$ \\
\hline 03595520 & $\begin{array}{c}\text { Grindstone Hollow Creek } \\
\text { at Manchester, Tenn. }\end{array}$ & $\begin{array}{l}\text { Urban } \\
\text { Rural } \\
\text { Regression }\end{array}$ & 3.11 & .54 & $\begin{array}{l}340 \\
350 \\
631\end{array}$ & $\begin{array}{l}500 \\
610 \\
941\end{array}$ & $\begin{array}{r}610 \\
800 \\
1,150\end{array}$ & $\begin{array}{r}770 \\
1,050 \\
1,440\end{array}$ & $\begin{array}{r}900 \\
1,260 \\
1,670\end{array}$ & $\begin{array}{l}1,050 \\
1,480 \\
1,900\end{array}$ \\
\hline 03607274 & $\begin{array}{l}\text { Bailey Fork Creek } \\
\text { Tributary at Paris, } \\
\text { Tenn. }\end{array}$ & $\begin{array}{l}\text { Urban } \\
\text { Rural } \\
\text { Regression }\end{array}$ & 1.44 & .31 & $\begin{array}{l}320 \\
410 \\
321\end{array}$ & $\begin{array}{l}480 \\
570 \\
483\end{array}$ & $\begin{array}{l}590 \\
680 \\
592\end{array}$ & $\begin{array}{l}750 \\
810 \\
746\end{array}$ & $\begin{array}{l}850 \\
900 \\
862\end{array}$ & $\begin{array}{r}960 \\
1,000 \\
981\end{array}$ \\
\hline 07027530 & $\begin{array}{l}\text { South Fork Forked } \\
\text { Deer River Tributary } \\
\text { at Jackson, Tenn. }\end{array}$ & $\begin{array}{l}\text { Urban } \\
\text { Rura 1 } \\
\text { Regression }\end{array}$ & .64 & 1.78 & $\begin{array}{l}530 \\
400 \\
544\end{array}$ & $\begin{array}{l}760 \\
560 \\
771\end{array}$ & $\begin{array}{l}930 \\
660 \\
922\end{array}$ & $\begin{array}{r}1,140 \\
780 \\
1,120\end{array}$ & $\begin{array}{r}1,300 \\
870 \\
1,280\end{array}$ & $\begin{array}{r}1,460 \\
960 \\
1,430\end{array}$ \\
\hline 07028985 & $\begin{array}{l}\text { Middle Fork Forked } \\
\text { Deer River Tributary } \\
\text { at Humboldt, Tenn. }\end{array}$ & $\begin{array}{l}\text { Urban } \\
\text { Rural } \\
\text { Regression }\end{array}$ & 1.85 & .27 & $\begin{array}{l}660 \\
600 \\
807\end{array}$ & $\begin{array}{r}940 \\
840 \\
1,160\end{array}$ & $\begin{array}{l}1,130 \\
1,000 \\
1,400\end{array}$ & $\begin{array}{l}1,400 \\
1,200 \\
1,710\end{array}$ & $\begin{array}{l}1,560 \\
1,350 \\
1,940\end{array}$ & $\begin{array}{l}1,740 \\
1,500 \\
2,160\end{array}$ \\
\hline 07030147 & $\begin{array}{l}\text { Town Creek Tributary } \\
\text { at Covington, Tenn. }\end{array}$ & $\begin{array}{l}\text { Urban } \\
\text { Rural } \\
\text { Regression }\end{array}$ & .97 & .11 & $\begin{array}{l}450 \\
350 \\
355\end{array}$ & $\begin{array}{l}620 \\
480 \\
508\end{array}$ & $\begin{array}{l}730 \\
570 \\
601\end{array}$ & $\begin{array}{l}870 \\
670 \\
738\end{array}$ & $\begin{array}{l}960 \\
750 \\
823\end{array}$ & $\begin{array}{r}1,060 \\
830 \\
913\end{array}$ \\
\hline 07031653 & $\begin{array}{l}\text { Wolf River Tributary } \\
\text { at Willey Road } \\
\text { at Germantown, Tenn. }\end{array}$ & $\begin{array}{l}\text { Urban } \\
\text { Rural } \\
\text { Regression }\end{array}$ & .72 & .26 & $\begin{array}{l}140 \\
180 \\
190\end{array}$ & $\begin{array}{l}200 \\
240 \\
261\end{array}$ & $\begin{array}{l}230 \\
280 \\
302\end{array}$ & $\begin{array}{l}280 \\
330 \\
363\end{array}$ & $\begin{array}{l}320 \\
360 \\
402\end{array}$ & $\begin{array}{l}350 \\
400 \\
442\end{array}$ \\
\hline 07031758 & $\begin{array}{l}\text { Cypress Creek at Broad } \\
\text { Street at Memphis, } \\
\text { Tenn. }\end{array}$ & $\begin{array}{l}\text { Urban } \\
\text { Rural } \\
\text { Regression }\end{array}$ & .86 & 2.85 & $\begin{array}{r}2,760 \\
920 \\
2,620\end{array}$ & $\begin{array}{l}3,850 \\
1,340 \\
3,580\end{array}$ & $\begin{array}{l}4,560 \\
1,610 \\
4,200\end{array}$ & $\begin{array}{l}5,410 \\
1,950 \\
4,940\end{array}$ & $\begin{array}{l}6,190 \\
2,200 \\
5,500\end{array}$ & $\begin{array}{l}6,840 \\
2,450 \\
6,050\end{array}$ \\
\hline 07031777 & $\begin{array}{l}\text { Lick Creek at Dickson } \\
\text { Street at Memphis, } \\
\text { Tenn. }\end{array}$ & $\begin{array}{l}\text { Urban } \\
\text { Rural } \\
\text { Regression }\end{array}$ & .88 & .34 & $\begin{array}{r}1,500 \\
710 \\
1,280\end{array}$ & $\begin{array}{l}2,140 \\
1,010 \\
1,800\end{array}$ & $\begin{array}{l}2,600 \\
1,210 \\
2,120\end{array}$ & $\begin{array}{l}3,180 \\
1,450 \\
2,550\end{array}$ & $\begin{array}{l}3,590 \\
1,640 \\
2,820\end{array}$ & $\begin{array}{l}4,010 \\
1,820 \\
3,100\end{array}$ \\
\hline 07032248 & $\begin{array}{l}\text { Cane Creek at East } \\
\text { Person Street } \\
\text { at Memphis, Tenn. }\end{array}$ & $\begin{array}{l}\text { Urban } \\
\text { Rura } 1 \\
\text { Regression }\end{array}$ & .91 & .16 & $\begin{array}{r}3,650 \\
930 \\
2,960\end{array}$ & $\begin{array}{l}4,850 \\
1,340 \\
3,990\end{array}$ & $\begin{array}{l}5,600 \\
1,610 \\
4,670\end{array}$ & $\begin{array}{l}6,560 \\
1,950 \\
5,460\end{array}$ & $\begin{array}{l}7,250 \\
2,200 \\
6,090\end{array}$ & $\begin{array}{l}7,970 \\
2,450 \\
6,700\end{array}$ \\
\hline $\begin{array}{l}3500360- \\
85173400\end{array}$ & $\begin{array}{c}\text { South Fork Dobbs Branch } \\
\text { at Chattanooga, Tenn. }\end{array}$ & $\begin{array}{l}\text { Urban } \\
\text { Rural } \\
\text { Regression }\end{array}$ & 1.52 & .17 & $\begin{array}{l}450 \\
140 \\
466 \\
\end{array}$ & $\begin{array}{l}615 \\
230 \\
681 \\
\end{array}$ & $\begin{array}{l}725 \\
300 \\
828\end{array}$ & $\begin{array}{r}865 \\
400 \\
1,020 \\
\end{array}$ & $\begin{array}{r}970 \\
480 \\
1,180 \\
\end{array}$ & $\begin{array}{r}1,080 \\
570 \\
1,340 \\
\end{array}$ \\
\hline
\end{tabular}

Precipitation factor (P2 24) is the 2-year, 24-hour rainfall amount, in inches, as determined by the U.S. Department of Commerce (1961) and shown in figure 6.

Basin development factor (BDF) is computed by subdividing the basin into thirds (upper, middle, and lower). Within each third, the presence or absence of four conditions is noted. These conditions are (1) storm sewers, (2) channel improvements, (3) impervious channel linings, and (4) curb and gutter streets. For each condition that is significant, a value of one is assigned. The total of all values for the basin equals the BDF. The range of BDF is 0 to 12. A value of zero for BDF does not necessarily mean the basin is non-urban. For a more complete description of the calculation and effects of the BDF, see the report by sauer and otners (1983).

Percentage of impervious area (IA) was measured using the grid method on recent aerial photographs and is the percentage of totai surface area in the drainage basin that is 


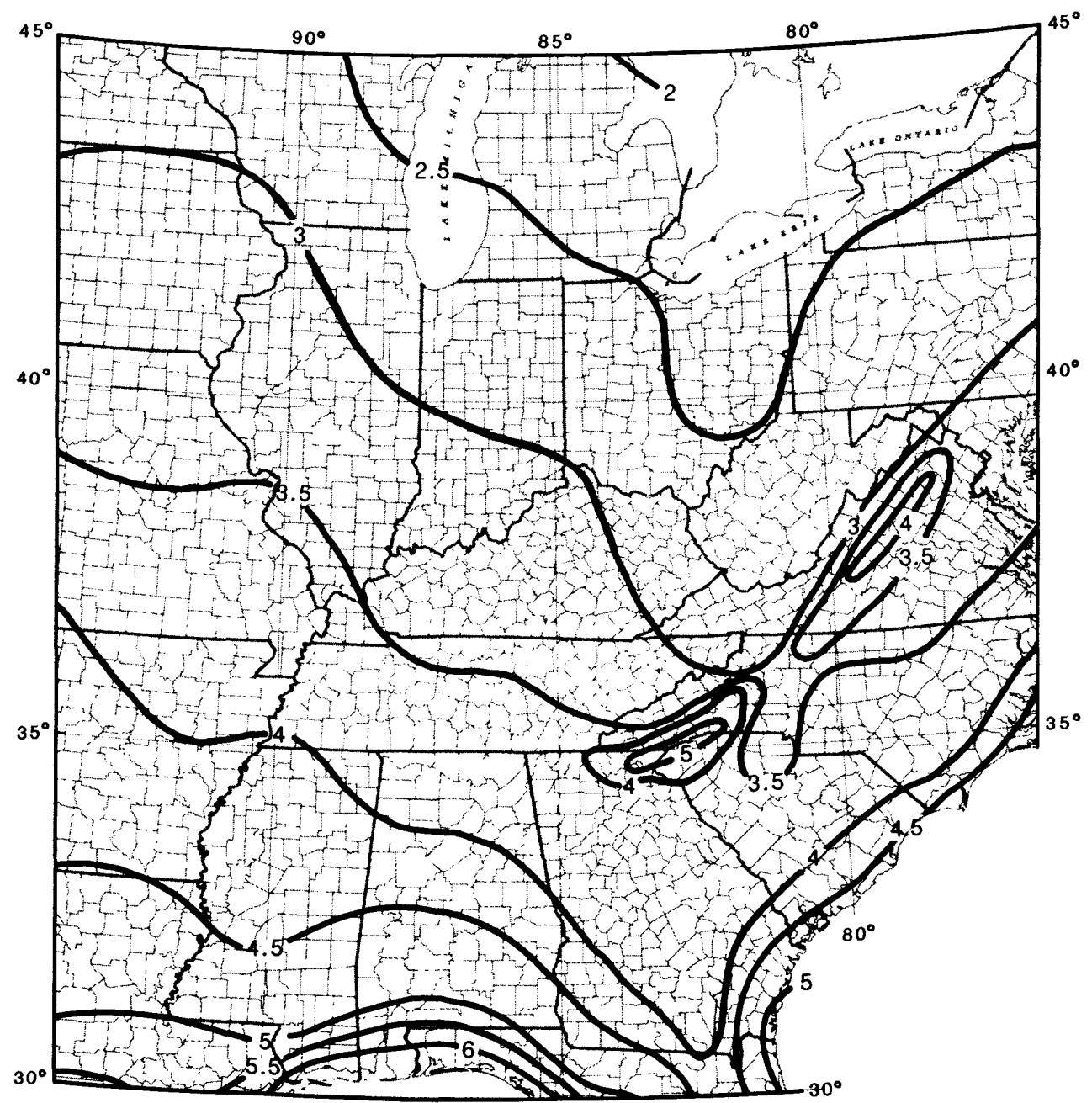

EXPLANATION

-5 Line of equal rainfall shows amount of 2-year 24-hour rainfall in inches. Interval 0.5 inch

Figure 6.-- 2-year 24-hour rainfall, in inches (U.S. Department of Commerce, 1961).

impervious. IA can also be measured from topographic maps or from population and industrial density reports.

Lag time (L) in hours, was obtained from the model calibration results $[\mathrm{L}=\mathrm{KSW}+0.5$ $(\mathrm{TC} / 60)$ ].

Mean annual precipitation (PRECIP) is the mean annual precipitation, in inches, for each gaging station as determined by the U.S. Department of Commerce (1961).

Peak discharge for rural conditions, $(Q(R))$. Methods used to estimate the magnitude and frequency of floods on rural streams for this report are taken from Randolph and Gamble (1976).

\section{Regression Analyses}

Stepwise and maximum $\mathrm{R}^{2}$ techniques were used with nine basin and climatic characteristics to derive equations for estimating flood magnitudes during the initial regression analyses. Channel slope, mean annual precipitation, and peak discharge for rural conditions were insignificant anã were deleted from successive regression analysis. The basin development factor was also deleted from successive analyses because 11 of the 22 gaging stations had BDF values less than or equal to 3. The $r$ ange of $B D F$ values for the remaining gaging stations was too narrow to be considered representative. 
The final regression analyses were performed using drainage area size, percentage of impervious area, and 2-year, 24-hour rainfall amount. These selected variables are readily available and are of practical use in estimating urban flood magnitudes in Tennessee. Drainage area size used in the regression analyses ranged from $0.21 \mathrm{mi}^{2}$ to $24.3 \mathrm{mi}^{2}$. The following table summarizes the distribution of drainage area size for stations used.

\begin{tabular}{cc}
$\begin{array}{c}\text { Range in drainage } \\
\left.\text { area size (mi })^{2}\right)\end{array}$ & $\begin{array}{c}\text { Number of stations } \\
\text { in analysis }\end{array}$ \\
\hline $0.00-0.50$ & 2 \\
$0.51-1.50$ & 5 \\
$1.51-4.00$ & 7 \\
$4.01-10.0$ & 6 \\
$10.1-25.0$ & $\frac{2}{22}$ \\
Total stations &
\end{tabular}

Impervious area (in percent) ranged from 4.7 to 74.0 percent. The following table summarizes the distribution of impervious area for the stations used.

$\begin{array}{cc}\begin{array}{c}\text { Range in impervious } \\ \text { area (percent) }\end{array} & \begin{array}{c}\text { Number of stations } \\ \text { in analysis }\end{array} \\ 0-10 & 3 \\ 11-20 & 7 \\ 21-30 & 6 \\ 31-40 & 2 \\ 41-50 & 2 \\ 51-75 & \frac{2}{22} \\ \text { Total stations } & \end{array}$

The 2-year, 24-hour rainfall amount ranged from 3.05 to 4.00 inches. The following table summarizes the distribution of rainfall amount for the stations used.

Range in

2-year, 24-hour

rainfall amount (inches)

$3.00-3.20$
$3.21-3.40$
$3.41-3.60$
$3.61-3.80$
$3.81-4.00$
Total stations

Number of stations in analysis

$\begin{array}{r}2 \\ 2 \\ 9 \\ 4 \\ 5 \\ \hline 22\end{array}$

The 2-year, 24-hour rainfall amount was not significant at the 5-percent confidence level in the 50- and 100-year recurrenceinterval equations. However, for consistency, it was used in all the equations. All the other regression coefficients are statistically significant at the 5-percent confidence level. Therefore, the following equations are recommended for estimating flood magnitudes for ungaged urban basins in Tennessee except for Memphis and Nashville. Specific flood-frequency methods previously have been derived which should be used for these two urban areas. Otherwise one equation for each recurrence interval applies statewide.
Standard error of regression, in percent

$Q(U)_{2}=1.76(A) 0.74($ IA $) 0.48\left(P_{2} 24\right) 3.01 \quad 32$

$Q(U)_{5}=5.55(A)^{0.75}(\text { IA })^{0.44}\left(P^{2} 24\right)^{2.53}$

$Q(U))_{10}=11.8(A)^{0.75}(\text { IA })^{0.43}(P 2 \overline{2} 4)^{2.12} \quad 27$

$Q(U)_{25}=21.9(A)^{0.75}(I A)^{0.39}(P 2-24)^{1.89} \quad 26$

$Q(U)_{50}=44.9(A)^{0.75}(\text { IA })^{0.40}\left(P^{2} 24\right)^{1.42}$

$Q(U)_{100}=77.0(A)^{0.75}$ (IA) $0.40(P 2-24)^{1.10}$

where $Q(U)$ is estimated urban discharge, in cubic feet per second, for the indicated recurrence interval.

A is the contributing drainage area, in square miles,

IA is the percentage of the contributing drainage basin occupied by impervious surface, and

P2 24 is the 2-year, 24-hour rainfall amount, in inches.

The standard error of regression represents the average difference between the observed value of a given recurrence-interval flood (the model estimate was used for this study) and the value for that same recurrenceinterval flood derived from the regression equation. These errors apply only to the continuous-record gaging stations used in the regression analyses. The standard errors of prediction associated with use of the equations to estimate flood magnitudes in ungaged streams are discussed in a later section of this report.

The log-linear form of the estimating equation was checked with graphical plots. The graphs included plots of regression residuals versus drainage area, residuals versus percentage of impervious area, residuals versus rainfall intensity, and residuals versus observed flood discharge. The scatter of plotting points on each graph appeared to be $r$ andom with no apparent bias. Therefore, the form of the estimating equation is assumed to be appropriate.

Station residuals were plotted on a map to evaluate geographic bias of estimates from the flood-frequency equations. Although the residuals varied considerably between some stations, no specific geographic trends could be detected.

A partial analysis of the sensitivity of the regression equations for the 2-, 25-, and 100-year urban flood magnitudes to arainage area (A), percentage of impervious area (IA), and the 2-year, 24-hour rainfall (P2_24) was performed. Results of sensitivity of the equations are given graphically in figure 7 . For the 2-year flood, for example, an error of 30 percent in computing drainage area results in about 20 percent difference in discharge, and an error of 30 percent in computing percentage of impervious area results in about 10 percent difference in discharge. Results of sensitivity are similar for the 25- and 100-year floods. Errors in computing 


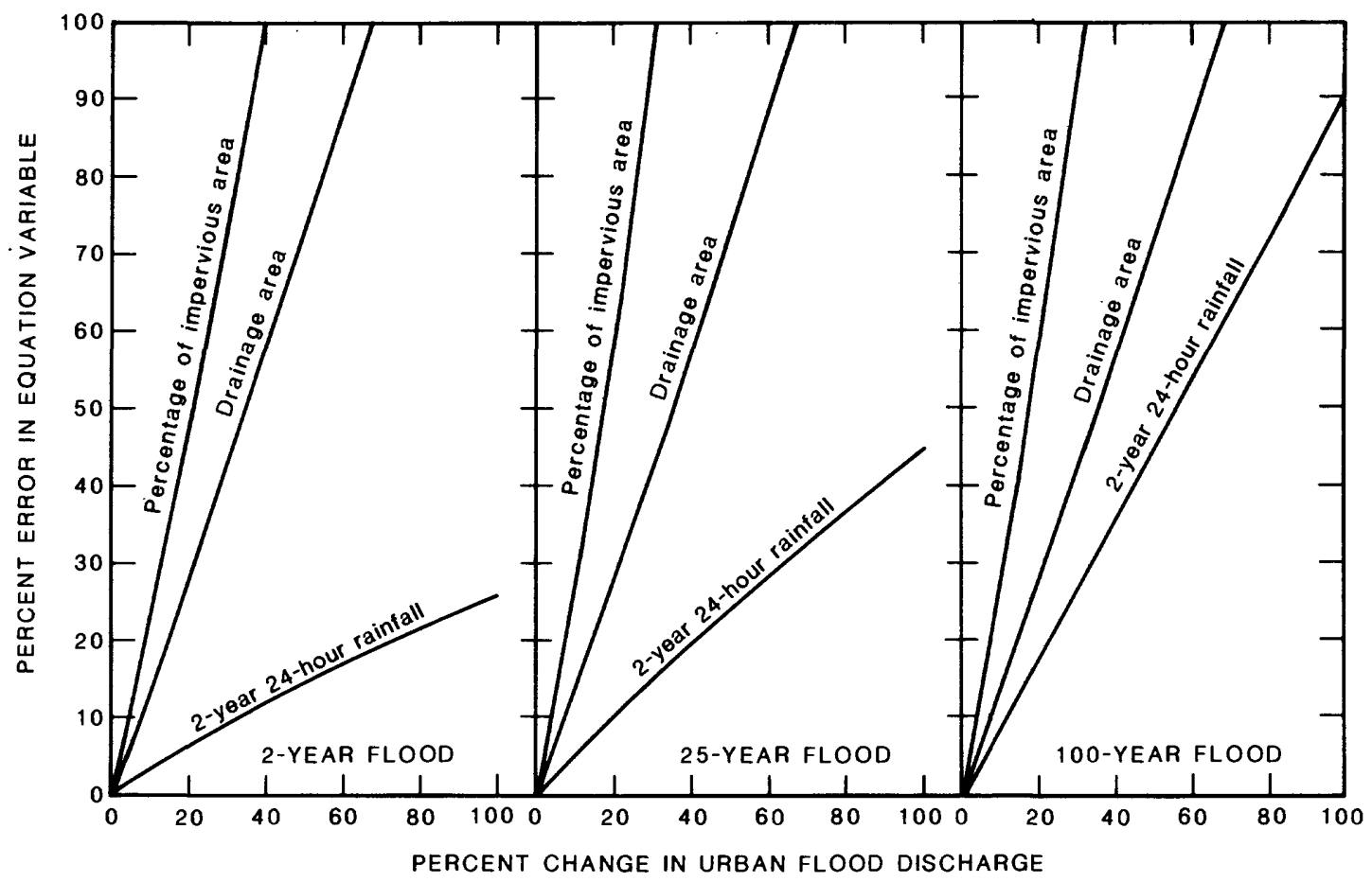

Figure 7.-- Percent change in urban flood discharge resulting from errors in computing drainage area, percentage of impervious area, and 2-year 24-hour rainfall.

the 2-year, 24 hour rainfail amount (fig. 6) cause the largest percentage of difference in urban flood discharge estimates. For example, an error of 20 percent in the rainfall amount estimate results in about 70 percent difference in discharge for the 2-year flood, and about 24 percent difference in discharge for the 100-year flood.

The most sensitive variable in each of the equations is the 2-year, 24-hour rainfall amount. Consequently, caution should be used when interpolating the value of this variable from figure 6. Rainfall amount is the only variable in the equations that is geographic in nature. Therefore, it is assumed that it explains the geographical variations in runoff in different parts of Tennessee. Therefore, the equations are assumed to be suitable for use in urban areas throughout Tennessee.

\section{APPLICATION OF ESTIMATING TECHNIQUES}

Methods for estimating flood discharges for ungaged streams draining urban areas consist of equations using drainage area, percentage of impervious area, and the 2-year, 24-hour rainfall. For any area in Tennessee, the 2-year, 24-hour rainfall can be obtained from figure 6. Graphical solutions for these equations to estimate $Q_{(U) 2,} Q_{(U) 5,} Q_{(U) 10,} Q_{(U) 25,} Q(U) 50$, and $Q$ (U) 100 are presented in figures $8,9,10$,
11,12 , and 13, respectively. The following example is given to illustrate use of the curves in figures 8 through 13 . The dashed $l$ ine and arrows on the figures indicate the procedure to follow.

$$
\begin{aligned}
\text { Drainage area } & =3.0 \mathrm{mi} 2 \\
\text { Percentage of impervious area } & =40 \text { percent } \\
\text { 2-year, 24-hour rainfall } & =3.50 \text { inches }
\end{aligned}
$$

Enter the figures with the appropriate drainage area along the top scale. Move downward to the percentage of impervious area curves to the $\mathbf{4 0}$ percent curve. Move horizontally to the 2-year, 24-hour rainfall curves to the 3.50 inches curve. Move downward to the urban flood discharge scale. The following results were obtained for this example:

$\begin{array}{ll}\text { from figure } 8, & Q(U) 2=1,010 \\ \text { from figure 9, } & Q(U) 5=1,520 \\ \text { from figure 10, } & Q(U) 10=1,870 \\ \text { from figure 11, } & Q(U) 25=2,240 \\ \text { from figure 12, } & Q(U) 50=2,650 \\ \text { from figure 13, } & Q(U) 100=3,040\end{array}$

The following computations demonstrate mathematical application of the regression equations to urban streams in Tennessee including a graphical plot (fig. 14) of the resultant flood-frequency curve. Assume a drainage area of $2.0 \mathrm{mi}^{2}$, a 60 percent impervious area, and a 2-year, 24-hour rainfall of 4.0 inches. Substitute the values of drainage area, percentage of impervious area, 


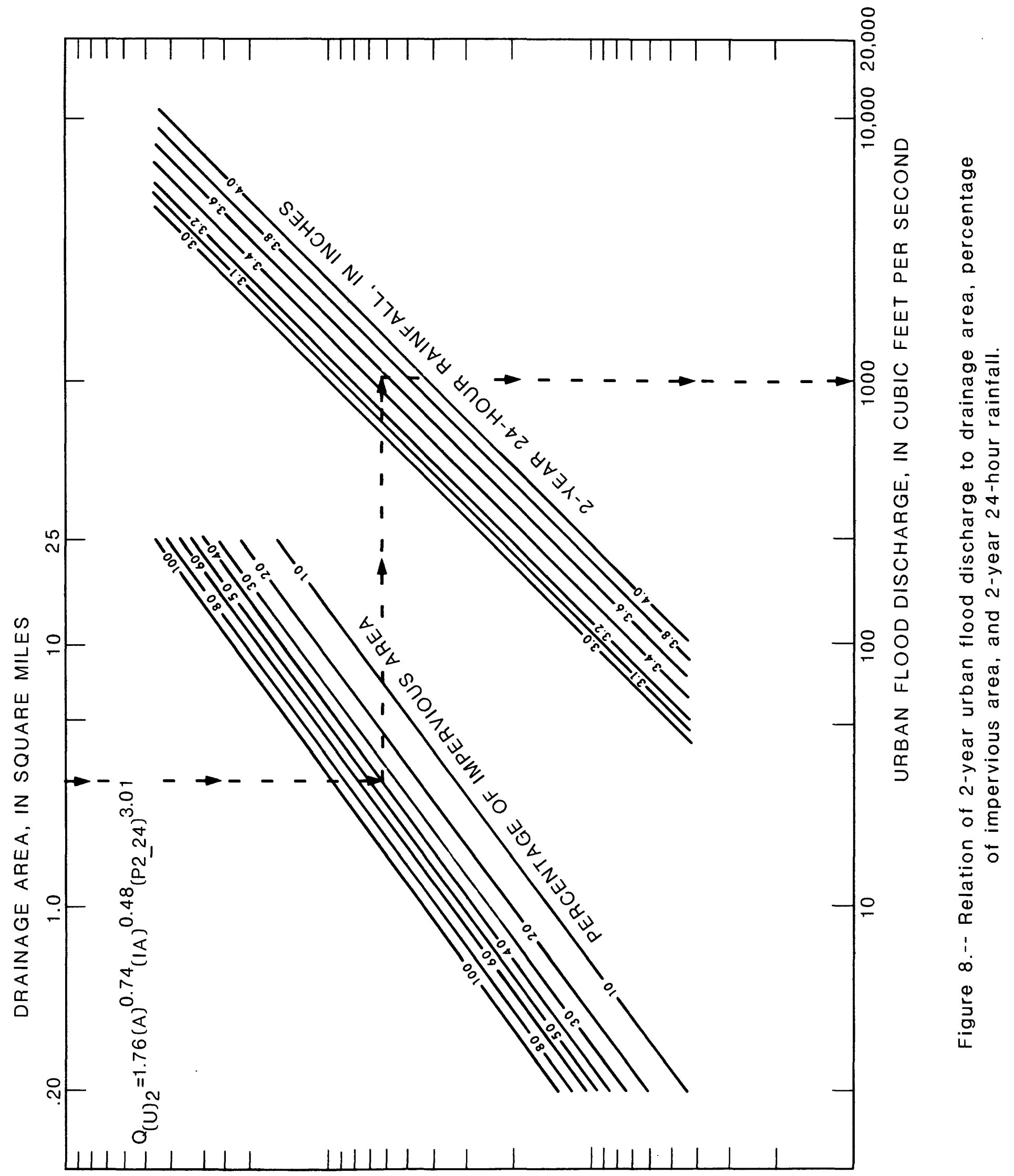




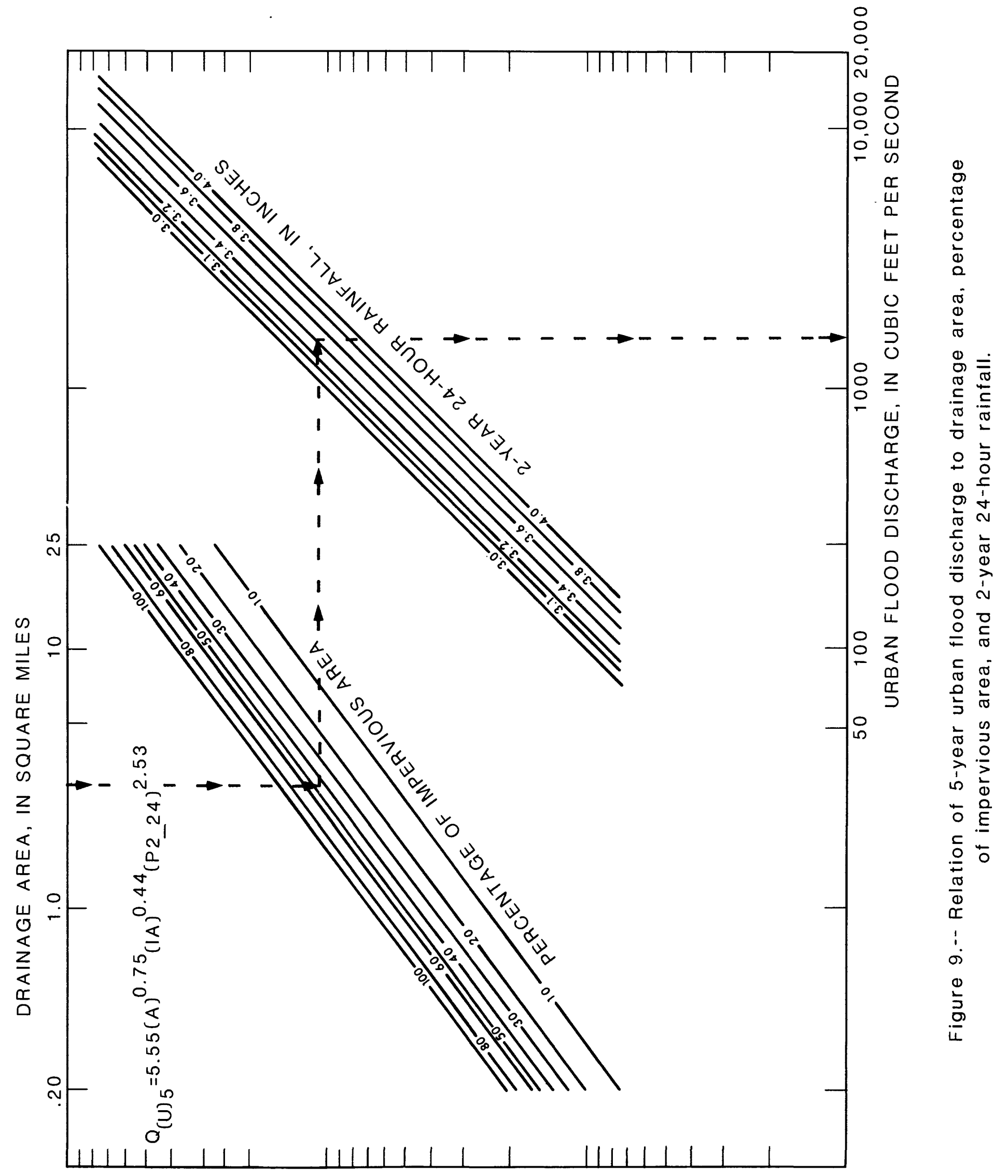




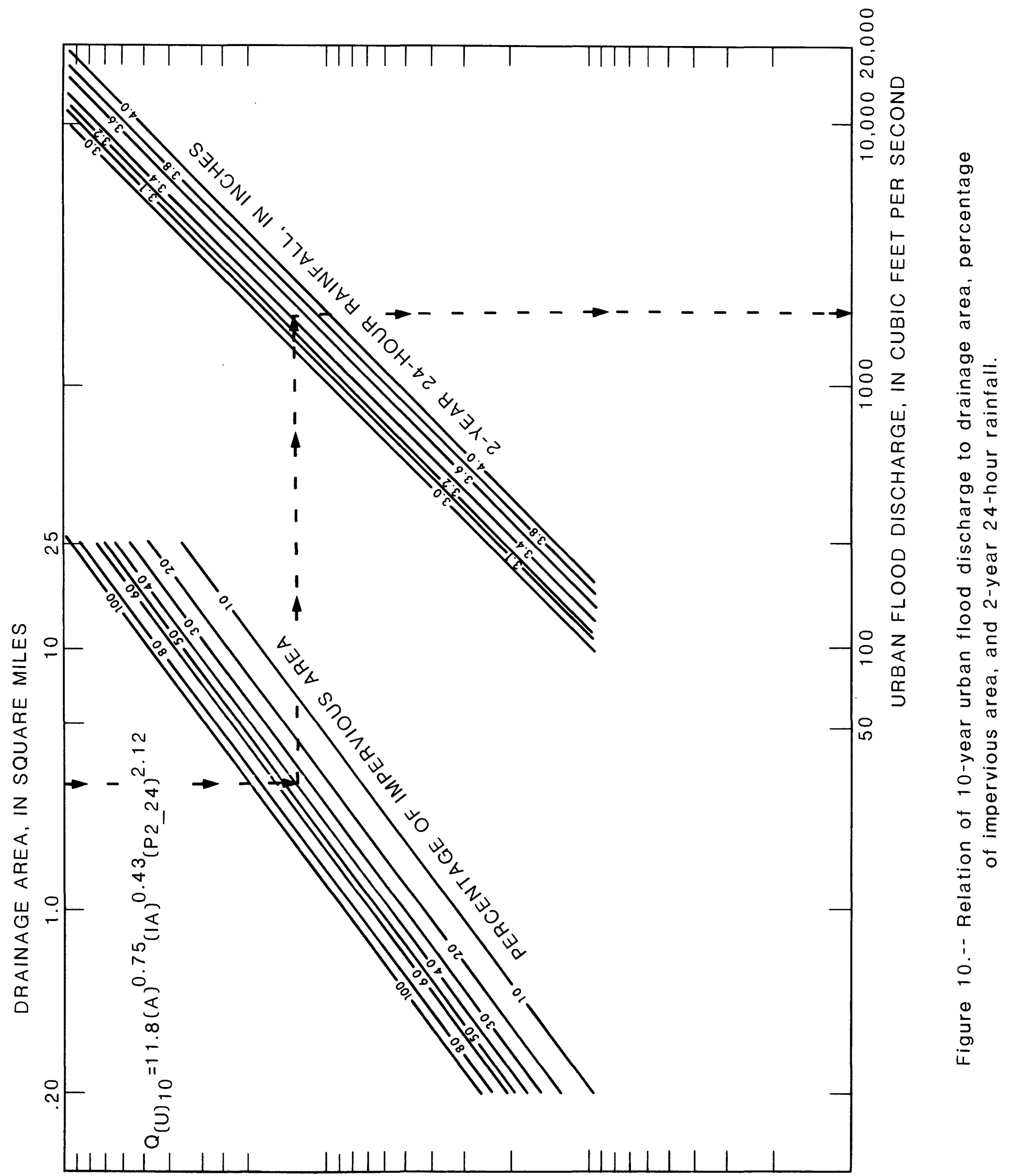




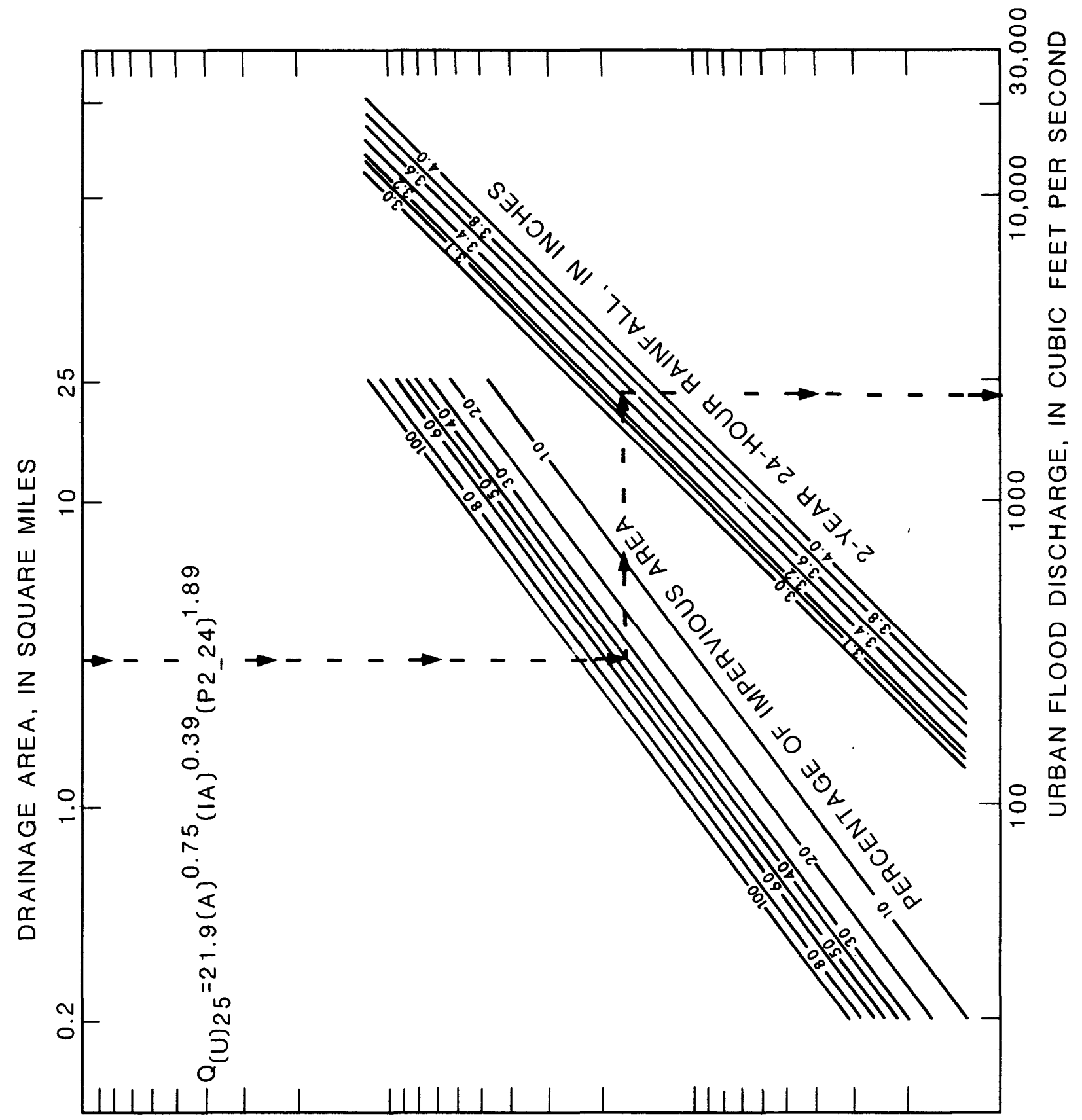

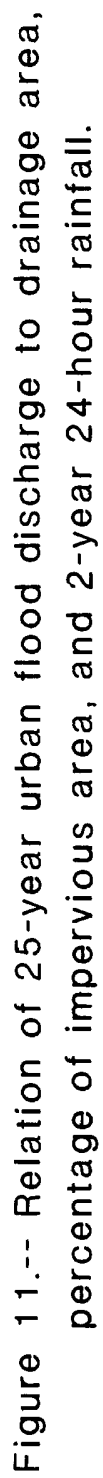




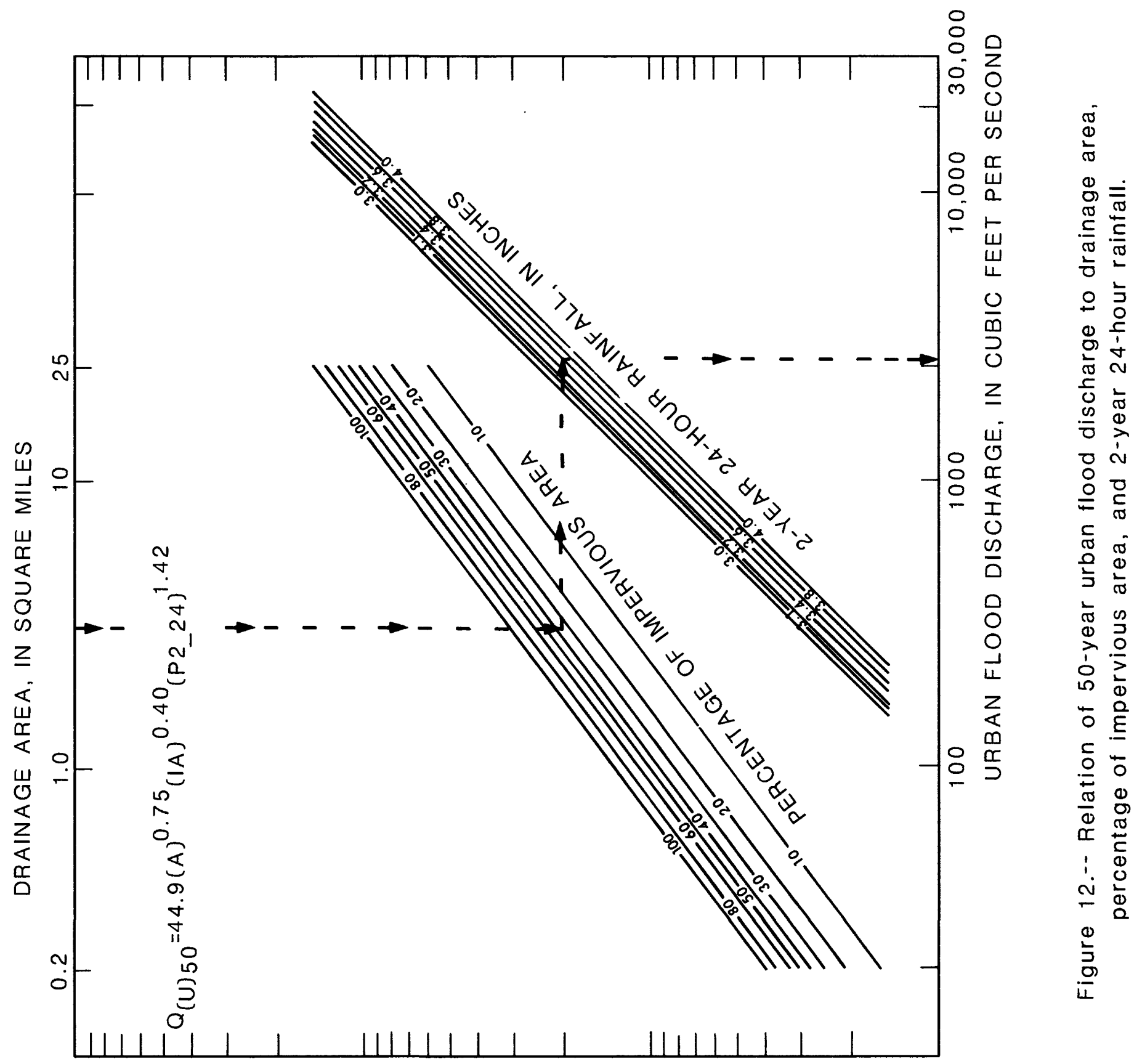




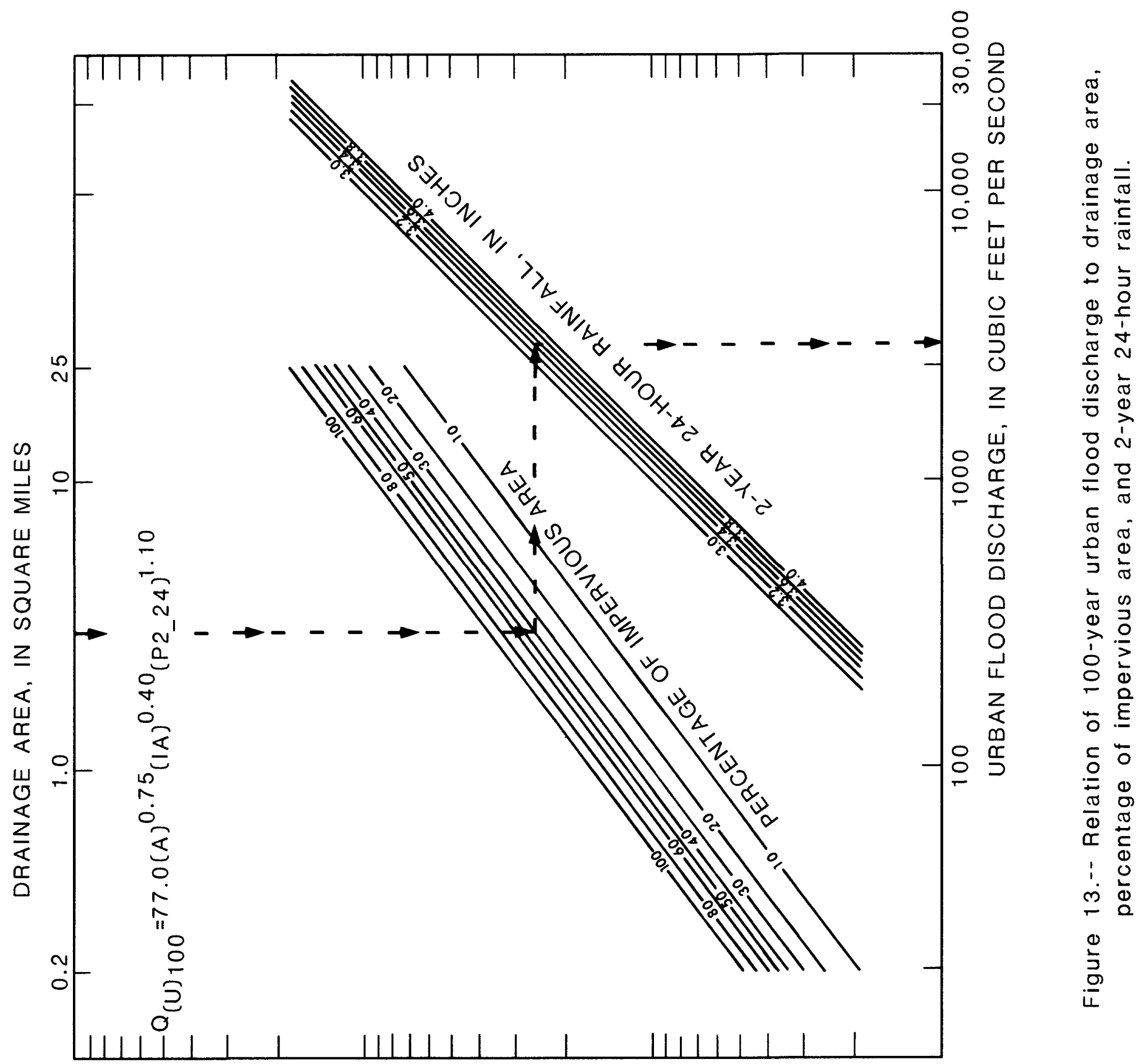




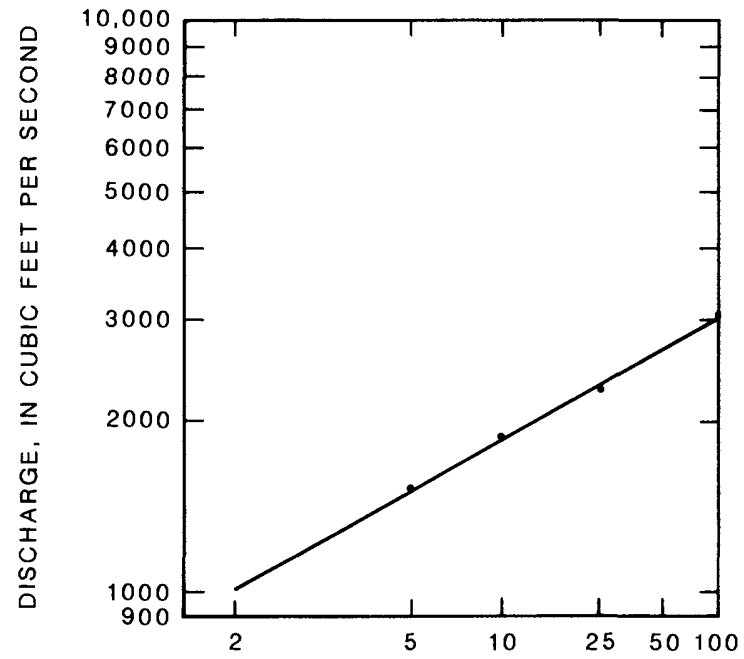

RECURRENCE INTERVAL, IN YEARS

Figure 14.-- Flood frequency curve for example computations.

and 2-year, 24-hour rainfall into the urban discharge equations, and estimate urban flood discharge as follows:

$$
\begin{aligned}
& Q(U) 2=1.76 \text { (A) } 0.74 \text { (IA) } 0.48 \text { (P2 24) } 3.01 \\
& Q(U) 2=1.76(2.0) 0.74(60) 0.48(\overline{4} .0) 3.01 \\
& Q \text { (U) } 2=1,360 \mathrm{ft}^{3} / \mathrm{s} \\
& \begin{array}{lll}
Q \text { (U) } 5 & =5.55 \text { (A) } 0.75 \text { (IA) } 0.44 \text { (P2 24) } 2.53 \\
Q & =5.55 \text { (U) } 5 \text { (2.0) } 0.75 \text { (60) } 0.4 \text { ( }^{2} \text { (0) } 2.53
\end{array}
\end{aligned}
$$

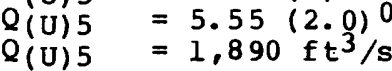

$$
\begin{aligned}
& Q(U) 10=11.8 \text { (A) } 0.75 \text { (IA) } 0.43 \text { (P2 24) } 2.12 \\
& Q(U) 10=11.8(2.0) 0.75(60) 0.43(\overline{4} .0) 2.12 \\
& Q(U) 10=2,180 \mathrm{ft}^{3} / \mathrm{s} \\
& Q(U) 25=21.9 \text { (A) } 0.75 \text { (IA) } 0.39 \text { (P2 24) } 1.89 \\
& Q(U) 25=21.9(2.0) 0.75(60) 0.39(\overline{4} .0) 1.89 \\
& Q \text { (U) } 25=2,500 \mathrm{ft}^{3} / \mathrm{s} \\
& Q \text { (U) } 50=44.9 \text { (A) } 0.75 \text { (IA) } 0.40 \text { (P2 24) } 1.42 \\
& Q \text { (U) } 50=44.9(2.0) 0.75(60) 0.40\left(\overline{4}^{2} .0\right) 1.42 \\
& Q \text { (U) } 50=2,780 \mathrm{ft}^{3} / \mathrm{s} \\
& Q(U) 100=77.0 \text { (A) } 0.75 \text { (IA) } 0.40 \text { (P2 24) } 1.10 \\
& Q(U) 100=77.0(2.0) 0.75(60) 0.40(\overline{4} .0) 1.10 \\
& Q(U) 100=3,060 \mathrm{ft}^{3} / \mathrm{s}
\end{aligned}
$$

Inspection of the T-year flood estimates in table 3 indicates that the urban synthetic flood-frequency for some sites is less than the equivalent rural flood-frequency. of the 22 gaging stations in this study, 41 percent of the urban flood-frequencies are less than the equivalent rural flood-frequency at the 100-year frequency, and 36 percent are less at the 2-year frequency. This condition is sometimes caused by time-sampling errors in the data and (or) modeling errors in the flood-frequency estimates; however, this condition occurs frequently enough to indicate that it may not always be the result of these errors. Some of the factors associated with the effects of urbanization, such as detention storage upstream from road fills and location of urbanization in the drainage basin, can reduce peak discharge. These and other unidentified urban effects may cause the reduction of urban flood peaks for some sites. However, detention storage was not considered to be significant in any of the 22 basins used in the analyses.

Another possible reason for the urban flood-frequency being less than the equivalent rural flood-frequency is that the rural flood-frequency equations for Tennessee (Randolph and Gamble, 1976) were derived using a range in drainage areas of $0.17 \mathrm{mi}^{2}$ to $3,035 \mathrm{mi}^{2}$. Of the 281 sites used in the rural flood-frequency study, approximately 68 percent (191) of the sites have drainage areas larger than $25 \mathrm{mi}^{2}$. The rural floodfrequency equations may be biased towards large drainage areas and thereby produce overestimated flood discharges for some basins having drainage areas less than 25 $\mathrm{mi}^{2}$.

\section{Limitations}

The regression equations described in this report are limited to estimating flood magnitudes of Tennessee streams draining urban areas. In deriving the equations, drainage areas ranged from $0.21 \mathrm{mi}^{2}$ to 24.3 $\mathrm{mi}^{2}$, percentage of impervious area ranged from 4.7 percent to 74.0 percent, and the 2-year, 24-hour rainfall ranged from 3.05 inches to 4.00 inches. Use of the equations should be limited to these ranges. If values outside these ranges are used, the standard error may be considerably higher than for sites where all variables are within the specified ranges.

The equations do not apply to urban streams where temporary in-channel storage or overbank detention storage affect the magnitude of peak flows, or where the percent of impervious area is less than 4.5. For the latter case, the basins should be considered rural and flood magnitudes should be estimated using methods given by Randolph and Gamble (1976) .

For the metropolitan areas of Menphis and Nashville where specific methods have been derived for estimating urban flood magnitudes, those methods should be used instead of the regionalized regression equations contained in this report.

\section{FLOOD FREQUENCY AT GAGED URBAN SITES}

Flood frequency at gaged urban sites of $0.21 \mathrm{mi}^{2}$ to $24.3 \mathrm{mi}^{2}$ in Tennessee should be estimated by combined use of the regression equations, or graphs, and the gagingstation frequency curves (Sauer, 1974). The combined, or weighted averages, are based on 
the equivalent years of record for the regression value and the number of years of station data. The equation (Sauer, 1974) used to compute the weighted average for selected recurrence intervals is:

$$
Q_{x(w)}=\frac{Q_{x(s)}(N)+Q_{x}(r)(E)}{N+E}
$$

where $Q_{x}(w)$ is the weighted discharge for recurrence interval $x$,

$Q_{x}(s)$ is the station value of the flood for recurrence interval $x$,

$Q_{x}(r)$ is the regression value of the flood for recurrence interval $x$,

$N$ is the number of years of station data used to compute $Q_{\mathbf{X}}(\mathrm{s})$, and

$E$ is the equivalent years of record for $Q_{X}(r)$.

The following table shows the equivalent years of record and the standard error of prediction for urban basins of 0.21 $\mathrm{mi}^{2}$ to $24.3 \mathrm{mi}^{2}$ in Tennessee for the indicated recurrence interval.
Recurrence interval

$$
\begin{array}{r}
2 \\
5 \\
10 \\
25 \\
50 \\
100
\end{array}
$$

Equivalent years of record

Standard error of prediction, in percent

$\begin{array}{ll}2 & 44 \\ 3 & 39 \\ 4 & 37 \\ 6 & 36 \\ 7 & 37 \\ 8 & 39\end{array}$

Estimates of equivalent years of record and standard error of prediction were computed by a method described by Hardison (1971). The accuracy of each regression equation is expressed as the standard error of prediction in percent. The standard error of prediction represents an estimate of the average difference between the true value of a given recurrence-interval flood and the value for that same recurrence-interval flood derived from the regression equation.

The standard error of prediction accounts for time sampling error, model calibration error, map-model error, interstation correlation error, and regression error. The prediction error term may be ambiguous, it is only an estimate. The true value (statistical mean) for any recurrence interval flood for any station is unknown. Therefore, only an estimate of the reliability of the regression equation to predict the true value (statistical mean) of any given recurrenceinterval flood for any station can be stated.

\section{SUMMARY}

Synthetic $T$-year annual flood estimates from a rainfall-runoff modeling procedure were used to derive flood-frequency relations for streams draining urban areas in Tennessee. A rainfall-runoff model was calibrated for 22 urban runoff sites with drainage areas ranging from $0.21 \mathrm{mi}^{2}$ to 24.3 $\mathrm{mi}^{2}$. Flood magnitudes for selected recurrence intervals were estimated by a map-model procedure developed by Lichty and Liscum (1978). Input data for that procedure include climatic factors and the calibrated parameters of the rainfall-runoff model. Flood magnitudes for selected recurrence intervals were also derived by direct application of the rainfall-runoff model for four sites in east Tennessee. Both methods gave similar results. The map-model method was used in computing flood-frequency curves for all sites.

Standard regression techniques were used to derive equations for estimating flood magnitudes for recurrence intervals of $2,5,10$, 25,50 , and 100 years. One equation for each recurrence interval applies statewide. Nine basin characteristics were tested in the analyses, but only drainage area, percentage of impervious area, and the 2-year, 24-hour rainfall were significant at the 5-percent confidence level. Standard errors of regression ranged from 25 percent for the 100-year flood to 32 percent for the 2-year flood. Errors for the 5-, 10-, 25-, and 50-year floods were within that $r$ ange. The equations do not apply to urban streams where temporary in-channel storage or overbank detention storage significantly affect the magnitude of peak flows, or where the percent of impervious area is less than 4.5. For the latter case, the basin should be considered rural and other equations should be used.

For the metropolitan areas of Memphis and Nashville where specific methods have been derived for estimating urban flood magnitudes, those methods should be used instead of the regionalized equations contained in this report.

\section{SELECTED REFERENCES}

Boning, C. W., 1977, Preliminary evaluation of flood frequency relations in the urban areas of Memphis, Tennessee: U.S. Geological Survey Water-Resources Investigations Report 77-132, $57 \mathrm{p}$.

Carrigan, P. H., Jr., 1973, Calibration of U.S. Geological Survey rainfall-runoff model for peak flow synthesis--natural basins: Reston, Virginia, U.S. Geological Survey open-file report, $109 \mathrm{p}$.

Clark, C. O., 1945, storage and the unit hydrograph: American Society of Civil Engineers Transactions, v. 110, p. 14191488 .

Dawdy, D. R., Lichty, R. W., and Bergmann, J. M., 1972, A rainfall-runoff simulation model for estimation of flood peaks for small drainage basins: U.S. Geological Survey Professional Paper 506-B, 28 p. 
Hardison, C. H., 1971, Prediction error of regression estimates of streamflow characteristics at ungaged sites: U.S. Geological Survey Professional Paper 750-C, p. $228-236$.

Horton, R. E., 1940, Approach toward a physical interpretation of infiltration capacity: Soil Science society of American Proceedings, v. 5, p. 399-417.

Lichty, R. W., and Liscum, F., 1978, A rainfall-runoff modeling procedure for improving estimates of $T$-year (annual) floods for small drainage basins: U.S. Geological Survey Water-Resources Investigations Report 78-7, 44 p.

Neely, B. L., Jr., 1984 , Synthetic flood frequency and storm runoff of urban areas of Memphis and Shelby County, Tennessee: U.S. Geological Survey Water-Resources Investigations Report 84-4110, 51 p. [in press ].

Olin, D. A., and Bingham, R. H., 1982, Synthesized flood frequency of urban streams in Alabama: U.S. Geological Survey Water-Resources Investigations Report $82-0683,39 \mathrm{p}$. [in press].

Philip, J. R., 1954, An infiltration equation with physical significance: Soil Science Society of America Proceedings, v. 77, p. 153-157.
Randolph, w. J., and Gamble, C. R., 1976, Technique for estimating magnitude and frequency of floods in Tennessee: Tennessee Department of Transportation, 52 p.

Robbins, C. H. 1984, Effects of urbanization on the magnitude and frequency of floods on small streams in Tennessee-Basic Data Report No. 3: U.S. Geological survey Open-File Report 84-242, 32 p.

Sauer, V. B., 1974, Flood characteristics of Oklahoma streams: U.S. Geological Survey Water-Resources Investigations Report $52-73,301 \mathrm{p}$.

Sauer, V. B.. Thomas, W. O., Jr., Stricker, V. A., and Wilson, K. V., 1983, Flood characteristics of urban watersheds in the United States: U.S. Geological Survey Water-Supply Paper 2207, 63 p.

U.S. Department of Commerce, 1961, Rainfall frequency atlas of the United States: Weather Bureau, Technical Paper No. 40, $61 \mathrm{p}$.

Wibben, H. C., 1976, Effects of urbanization on flood characteristics in NashvilleDavidson County, Tennessee: U.S. Geological Survey Water-Resources Investigations Report 76-121, 33 p. 